Kaygı, 18(1)/2019: 75-113. Araştırma Makalesi | Research Article

Makale Geliş | Received: 09.01.2019

Makale Kabul | Accepted: 30.01.2019

Yayın Tarihi | Publication Date: 15.03.2019

DOI: 10.20981/kaygi.520269

Ömer Faik ANLI

Doç. Dr.| Assoc. Prof. Dr.

Ankara Üniversitesi, Dil ve Tarih-Coğrafya Fakültesi, Felsefe Bölümü, Ankara, TR Ankara University, Faculty of Languages History and Geograpgy, Department of Philosophy, Ankara, TR ORCID: 0000-0002-5621-5145 oanli@ankara.edu.tr

\title{
Post-Modern Epistemoloji Otopsisine Karşı Bilgi Kuramsal Bir Tez: Kant-Popper- Rorty
}

Öz

$\mathrm{Bu}$ makale, epistemolojinin ölümü tezini, epistemolojinin varlık nedeni olan gerçek bir problemin var olup olmadığı temelinde tartışmaya açmaktadır. Bu tartışma iki alt konum üzerinden yürütülürken (Rorty’ye karş1 Popper), epistemolojinin metinler-arası olmayan ve dil oyunlarını aşan gerçek bir probleminin var olduğu (yani Poppercı konum) savunulmaktadır. Bu savunu, özellikle bilim teorisi üzerinden geliştirilmekte ve günümüzün somut probleminin bilim problemi olduğu savlanmaktadır. Buna göre, iki karşıt konum özellikle Kant'ın epistemolojisinden hareketle farklılık göstermektedir. Bu savı çerçeveleyen meta-hipotez epistemoloji-bilgi teorisi-bilim teorisi tarihsel hattının, Kant ile birlikte çeşitlenen evrimsel bir süreç olduğudur. Kant, bu hipotezin kaynağında yer alan Popper Teorisinin genetik atasıdır. Diğer yandan, bir meta-teori olarak Rorty Teorisinin çerçevelediği epistemolojinin ölümü tezinde Kant, epistemolojinin ölümünün tarihsel kırılma anı ve hatta kanıtıdır. Popper Teorisi, epistemoloji üzerine bir meta-teori olarak kullanıldığında, iki meta-teori Kant'ta kesişmekte ve Kant üzerinden çeşitlenen kuzen-teoriler olarak konumlanabilmektedirler. Bu hipotez kabul edilerek izi sürüldüğünde, bilim problemine ilişkin bilim teorilerinin empirik içerikleri olduğu ve doğru oldukları ölçüde gerçekliğe müdahale edebilecekleri hipotezinin güçlü olduğu gösterilmeye çalışılmıştır. Hipotezin gücü 'temsil' kavramından ve pragmatizmden gelmektedir. Epistemoloji, nesnesiyle ilişkisinde evrimsel olarak dönüşen ve mevcut hali Einstein Devrimine verdiği tepki üzerinden biçimlenmiş bir metateoridir ve 'ölmemiştir'. Ulaşılan bu 'sonuç', epistemoloji üzerine geliştirilebilecek bir meta-hipotezdir (en azından bu çalışma sınırlarında) ve "epistemolojinin ölümü” problemiyle ilişkili bütün bir problem ağını aydınlatma ve bu ağın büyük bir bölümüne çözüm getirme potansiyelini barındırmaktadır.

Anahtar Kelimeler: Epistemoloji, Kant, Rorty, Popper, Temsil, Pragmatizm.

\section{An Epistemological Thesis Against a Post-Modern Autopsy of Epistemology: Kant- Popper-Rorty}

\footnotetext{
Abstract

This article opens a discussion on the thesis of the death of epistemology on the basis of whether there is a real problem that is the cause of epistemology. While this discussion is carried out in two sub-positions (Popper versus Rorty), it is argued that epistemology has a real problem beyond intertextual contexts and language games. This advocacy is developed especially through the theory of science and it is argued that today's concrete problem of epistemology is a science problem. Accordingly, the two opposing positions differ in particular over Kant's epistemology. This framework of the advocacy is based on the meta-hypothesis that the historical line of epistemology-theory of knowledge- theory of science is an evolutionary process that diversifies with Kant. Kant is the genetic ancestor of the Popper Theory at the source of this hypothesis. On the other hand, in the thesis of the death of the epistemology framed by the Rorty Theory as a meta-theory, Kant is
} 
the historical break and even proof of the death of epistemology. When the Popper Theory is used as a metatheory on epistemology, two meta-theories intersect in Kant and can be positioned as cousin-theories diversified through Kant. When this hypothesis is accepted and followed it has been tried to show that the hypothesis is very strong which argued that theories of science on science problem has empirical contents and that they can intervene in reality as long as they are true. The power of the hypothesis comes from the concept of representation and pragmatism. Epistemology is a meta-theory that has evolved evolutionarily in its relation to its object, and its current form is the response to the Einstein Revolution, and so epistemology is still alive. This result is a meta-hypothesis that can be developed on epistemology (at least at the limits of this study) and has a potential to illuminate an entire network of problems associated with the problem of the death of epistemology. Also it has a potantial to solve a large part of this network.

Keywords: Epistemology, Kant, Rorty, Popper, Representation, Pragmatism.

Dostlar, Romalılar, yurttaşlar, dinleyin; Ben Caesar'l gömmeye geldim, övmeye değil. Insanin ettiği kötülük yaşar ardindan, İyilikleriyse toprağa gider kemikleriyle. Burakın, öyle olsun Caesar için de. (William Shakespeare, Julius Caesar)

\section{Problem}

Felsefe tarihinde -konu edinilen- problemlerin ortaya çıkış ve gözden kayboluşları, disipliner gündem ve / veya entelektüel modalar ile açıklanamaz. Bu tarihte görünür olan problemlerin ortaya çıkış ve kayboluş yüzeyi disipliner gündemi oluştururken (ve pekâlâ da modadan etkilenebilirken), yüzey-altı daima gerçekliktedir. Felsefe ve düşünce tarihi, gerçekliğe ilişkin problemler ve çözüm önerileri (/çözümler) tarihidir. Ancak 'gerçekliğe ilişkin problem' ne anlama gelmektedir? Bu sorunun kendisi de felsefi (ontolojik ve belki de epistemolojik) bir sorudur. Felsefe problemleri, dilsel dönüş (linguistic turn) ile birlikte iddia edildiği gibi yüzeyin daha derinindeki yeni varsayımlar veya söz dağarları (vokabülerler) değişimlerinin sonucu olan kılık değiştirmeler midir yoksa dilin dışına da taşan edimsel problemler midir? Diğer bir deyişle, "bir felsefi problem, içinde dile getirildiği vokabülerle inşa edilen varsayımların (problemin kendisi ciddiye alınmazdan önce sorgulanmış olması gereken varsayımların) bilinçsiz bir adaptasyonunun ürünü” (Rorty 2006: 3) müdür yoksa dilin (vokabülerlerin / dil oyunlarının / metinler-arasılığın) ötesine taşan ciddi felsefi problemlerin 
mevcudiyeti ve bunları çözebilme potansiyeline bağlı olarak felsefenin dil felsefesini aşan meşru varoluşu (Popper 2010: 191) mu söz konusudur? Bu iki konum alış, epistemolojinin varlık nedeni olan gerçek bir problemin var olup olmadığı veya epistemolojik problemin nasıl bir nitelik arz ettiği konusunda anlaşamayan iki altkonum içermektedir.

İlk konuma göre, epistemolojinin kendi üretmediği, yani dil oyununun kural ihlallerine bağlı olmayan (epistemoloji adı verilen dil-oyununa aşkın ya da dışsal) bir problemi yoktur. Hatta bir adım ötede, genel olarak epistemoloji adı verilen dil oyunları seti, 'bilgi' üretme ve içerme iddiasındaki tüm dil oyunları üzerine çeşitlenebilen bir meta-dil oyunu ailesidir. Susan Haack' in başka bir bağlamdaki tespiti (2017: 41) buraya uyarlanacak olursa, "epistemoloji", fazla kullanılmış, bu nedenle tahrif olmuş ve dikkati odaklamaktan ziyade dağıtmaya başlayan bir aile adına dönüşmüştür; o kadar ki, 'eksantrik teyzeler', 'alkolik amcalar', 'yaramaz çocuklar', 'testosterondan delirmiş ergenler' ve eski zafer günleri için savaşmaya devam eden 'büyük büyük babalar'dan oluşan bu aileyi bir arada tutan genetik bağ artık görünür değildir. Bu ilişkiye uygulanacak bir terapi, ortada gerçek (aşkın / dışsal) bir problemin olmadığını ve epistemolojinin artık -belki de başından beri- bir boş-gösteren olduğunu gösterecektir. Yani epistemoloji, felsefe için 'konusu (araştırma problemi) olmayan' bir konu, bir psödo-disiplindir.

İkinci konuma göre, epistemoloji kendi dışında var olan bir probleme dairdir ve bu probleme (ya da problem setine) ilişkin doğru / yanlış olabilecek teoriler üretilebilecek bir meta teorik-çerçevedir. Diğer bir deyişle, epistemoloji teorilerinin empirik içeriği ve doğru olduğu ölçüde gerçekliğe müdahale edebilme potansiyeli vardır. Öyle ki, Poperyen konuma göre, bilgi üretim pratiğine dair teorik bir kavrayış, bu pratiğin sürdürülebilirliğini ve genişletilebilirliğini olanaklı hale getirecek biçimde 'model' biçiminde geliştirilebilir. Empirik olarak bilgi üretimini olanaklı kılan gerek ve yeter koşullar setinin belirlenmesi ve bu koşulların teorinin kurduğu değil, hakkında olduğu şeyler olmaları, epistemoloji teorilerinin de snanabilir olmasını ve teoriden 
normatif olana geçilmesini sağlamaktadır. Bu anlamda "teorik problemler, özünde açıklama bekleyen, açıklayıcı teoriler bekleyen sorulardır: Teorilerin sundukları deneme amaçlı yanıtlar, zaten açıklama denemeleridir" (Popper 2015: 28). Bu denemelerin sınanarak elenmesi de olanaklıdır. Eğer böylesi bir olanaklılık mevcutsa epistemoloji teorileri spekülatif yorumlar çoklusu değil demektir. Bu da eski bir problemle ardılı olan yeni problem(ler) arasında (bir kopuş değil) bir mesafe olması anlamına gelmektedir. İlginç bir biçimde, Rortyci konum da epistemolojinin bir spekülasyon alanı olmadığını savunmak durumundadır, çünkü açık bir biçimde epistemolojinin sonu, yerine bir ikame olmaksızın ilan edilmektedir. Her iki konum da bu dünyaya ilişkindir (bu anlamıyla doğalcıdır), a priorizme karşıttır ve bilimselliği aşacak bir bilginin olanağını kabul etmemektedir.

Bu iki konum alışın mevcudiyeti, felsefi açıdan ilginç bir meta-problem açığa çıkarmaktadır: Kendi ortaya koydukları çerçeve gereği iki konum da yanlış olabilir, fakat ikisi de doğru olamaz. Biraz zorlama bir benzetmeyle, epistemolojinin varlık nedeni olan problem, mevcut durumda 'Schrödinger'in Kedisi'nden farklı olarak ya vardır (yaşıyordur) ya da yoktur (ölmüştür ya da hiç var olmamıştır). Dolayısıyla, problem odaklı bir felsefi yönelimde epistemoloji, epistemolojik-problemin varlığına bağlı olarak ya yaşıyordur ya da ölüdür. Bu çalışmanın konu edineceği problem, bu anlamda 'derin bir varsayıma' bağlı olan “epistemolojinin ölümü problemi”dir. Eğer bu varsayım geçerliyse ve felsefenin kadim alt alanı olan epistemoloji ölmüş ve postmodern bir otopsinin (post-mortem) nesnesi haline gelmişse bile en azından Ceasar gibi gömülmeyi hak etmektedir.

\section{Çerçeve}

$\mathrm{Bu}$ çalışma, epistemolojiyi meta bir konumlanmayla problem odaklı olarak konu edinirken, kendisi de bir boyutuyla epistemolojik bir çalı̧̧ma olduğundan, refleksif bir duruma da düşmektedir. Epistemolojinin ölümü tezini irdeleyen epistemolojik bir araştırma olmanın kısır döngüsünü kırabilmek için araştırma problemi üçlü bir 
kavramsallaştırmayla çerçevelenmektedir. Bu kavramlar, 'temsil' (representation), 'gerçeklik' (reality) ve 'görüntü'dür (appearance). Bu üç kavram arasındaki problematik ve hatta 'gerçeklik' kavramının kendisi 'temsil' ile başlar. Dilin kökenini epistemolojiyle ilişkilendiren tespit ise şudur:

Dil bir temsile 'bu gerçektir' denmesiyle başlar. (...) Gerçeklik antropomorfik bir yaratıdır. Gerçeklik insan ürünü olabilir, ancak o bir oyuncak değildir, bilakis o insan yaratılarına göre ikincildir. İlk büyük insan icadı temsildir. Bir defa temsil etme işi yapılabildiğinde, ikinci dereceden bir kavram bunu takip eder. Bu gerçeklik kavramıdır, ancak birinci dereceden temsiller var olduğunda içeriği olan bir kavram (Hacking 2016: 172).

Tespitin ana fikri kolaylıkla bir tür idealizm ile karıştırılabilir görünmektedir. Ancak böylesi bir karıştırma ontolojiyi önceleyen bir bakışın ürünüdür. Gerçeklik, insan dilinden önce de vardır. Gerçekliğin 'gerçeklik' olarak kavramsallaştırılması ise zorunlu olarak temsile göreli olarak ikincildir. Bu, aynı zamanda epistemolojinin ontolojiye öncelenmesidir. $\mathrm{Bu}$ bakış açısına göre, önce temsillerin yapımı gelir, ardından "temsillerin gerçek ya da gerçek dışı, doğru ya da yanlış, sadık ya da sadakatsiz şekilde yargılanması" söz konusu olur. Sonunda da dünya ortaya çıkar (Hacking 2016: 172). Tam bu noktada, çalışmanın sınırını ontoloji tartışmasına, diğer bir deyişle realist bilim teorisine ya da fizikalizm tartışmasına dek uzatmayacağımın altını çiziyorum. Bunun ilk nedeni, ‘epistemolojinin ölümü tezi’nin halen epistemoloji odaklı olarak tartışılmasının potansiyellerini (özellikle bilim teorileri arası ilişki problemine dair çözüm potansiyelini) tüketmediğini düşünmem, diğeri ise ilk nedenle ilişkili olarak makale sınırını koruma gerekliliğidir.

Doğruluk ve onunla ilintili olarak bilgi problemi, temsilin alternatif tarzlarının açığa çıkmasıyla doğmuştur. İnsanın hiç görmediği, dokunmadığı ve koklamadığı varlıklar ya da burada ve şimdi el-altında bulunmayan şeyler hakkında konuşabilmesini olanaklı kılan temsilin mümkünlüğüdür. Ancak, her temsil eş-değer değildir. İşte bu eşdeğer olmama durumu alternatif temsiller arasında farkın neye göre ve nasıl belirleneceği problemine yol açar. Karl Popper (2015: 89) bu problemin tarihini insana özgü dilin (o bu terimi kullanmasa da esasında insana özgü dilden ziyade bir insan 
türüne özgü, yani Sapiense özgü dilin) icadıyla bağlantılandırır ve bir bildirinin doğru mu, yoksa dileklerle süslenmiş bir uydurmaca mı (yani avcı palavrası) olduğu problemiyle birlikte hayati önemdeki doğruluk probleminin başladığını savlar. Böylece, antropolojik olarak pre-epistemoloji tarihinden söz etmek mümkün hale gelmektedir.

'Avcı palavrası'sın mevcudiyeti, her 'avcı hikayesi'nin 'palavra' olduğu anlamına gelmez. Epistemolojik soru şudur: Hangi hikâye(ler) palavra, hangi hikâye(ler) değil ve bir 'hikâye'nin 'palavra' olmaması ne anlama gelmektedir? Alternatif temsiller ya da temsil tarzları (sistemleri) olmaksızın doğruluk ve gerçeklik problemleri de var olamazlar. Ancak bu problemlerin teorik teşhisi (ve dahi teorik çözümü) için gerekli olan epistemoloji, problemlere göreli olarak oldukça gençtir. Ancak doğa biliminin kökenindeki doğa felsefesinde alternatif temsiller yarışmaya başladığında (Thales, Anaksimandros, Anaksimenes, Demokritos, Empedokles vd.), bir yandan da Parmenides'le birlikte 'episteme' (bilgi) / 'doksa' (kanı) ayrımı entelektüel gündeme getirilebilmiştir. Bu 'ilk temsiller' pür ontoloji gibi görülüp 'kutsansa' dahi, epistemoloji olmaksızın daima eksiktirler. Çünkü esas 'gerçeklik problemi', epistemoloji olmaksızın kavranamaz. Bu nedenle, yukarıda da belirtildiği üzere, epistemoloji odaklı araştırmanın potansiyelini tükettiği temellendirilmiş biçimde gösterilmeden 'ontolojiye geri dönüş’ esasında epistemolojik bir savrulmayla sonuçlanabilir. Ancak bu savrulmadan kaçınmanın yolu da bir asal gerilim noktasından çıkış almaktadır: Mevcutta epistemolojinin kendisi (bilim felsefesini de kapsayacak biçimde) bir avcı palavrası mıdır değil midir?

Hemen belirtmeliyim ki, bu girizgâh, makalenin inceleme konusunun taraflarından biri olan Rorty'nin tam da karşı olduğu 'temsil' ve 'epistemoloji' bağlantısını esas almaktadır. Diğer bir deyişle, bu makalede 'tarafsız' bir konum ve bu konumdan 'kuşbakışı' incelenen iki akım ve / veya düşünür söz konusu değildir. Çünkü makalenin çerçevesinin kurulduğu tüm savlarla çelişecek biçimde konumlanan postmodern tavır, Rorty'nin Felsefe ve Doğanın Aynası adlı eserinin amacını belirttiği şu ifadelerde kendisini gösterir: "Bu kitabın amacı, okuyucunun (...) hakkında bir "teori" 
bulunması gereken ve "temellere" sahip bir şey olarak "bilgi"ye ve Kant'tan bu yana anlaşılmış olduğu şekliyle "felsefe"ye beslediği güvenin altını kazımaktır" (Rorty 2006: 13). Bilgi, hakkında bir teori bulunması gereken ve bir 'temel'e sahip bir şey değilse, epistemoloji bir yanılgı demektir. Bu durumda da epistemoloji ya ölmüştür ya da hiç var olmamıştır. ${ }^{1}$

Rorty’nin anti-Kantçı devrim adını verdiği bir dönüşümün ürünü olan post-Kantçı kültür, Kant'ın (daha sonra değinilecek olan) ünlü sorusunu tersine çevirmektedir: Acaba epistemoloji gibi bir şey olanaklı mıdır? Kant'ın kendi döneminde bir zamanlar tüm bilimlerin kraliçesi olarak adlandırılan ve konumlandırılan metafiziğin düştüğü durumu ifade edişi, bu kez epistemoloji için dile getirilmektedir: "Biraz önce her şeyin en büyüğü, tüm soyunda güçlü... şimdi sürgünde meteliksiz" (Kant 2015: 15). Modern bilim çağında, "bilimlerin kraliçesinin" kendisinin de bir bilim olması gerekmektedir. Eğer durum buysa, epistemoloji (ya da felsefe) bir bilim midir? Daha da önemlisi, George A. Reisch'ın mantıksal empirizmin asli amacına ilişkin tespitine (2016: 17) gönderimli olarak şu sorulmaktadır: Bilimlerin ve daha temelde bilimselliğin modern yaşamın bilinçli olarak şekillendirilmesi ve planlanmasına dönük alet(ler) olarak daha iyi kullanılması için epistemoloji gerekli midir? "Gerici ve bilim-karşıtı çevrelerden gelen obskürantist retorik" halen bir tehlike midir ve bunun epistemolojiyle bir ilgisi var midir?

Bu çalı̧̧mada, bu sorular bağlamında ölmüş olan epistemolojiyi gömen Richard Rorty ile epistemolojiyi ‘öven' Karl Popper'n düşünceleri karşılaştırılmakta ve epistemoloji probleminin önemli, ciddi ve ele alınmasının ivedi olduğu Immanuel Kant'ın açığa çıkardığı düşünsel sapak üzerinden ele alınmaktadır. Bu ele alış, Roy Bhaskar'ın 'metodolojik eleştiri' olarak adlandırdığı eleştirel konumlanışa bağlidır. Buna göre, "eğer bir bilim izahatı kendi olanaklılığı ile tutarsız ise, buradan onun uygulamaya geçirilemeyeceği sonucu çıkar" (Bhaskar 2017: 185). Bir bilim izahatının klasik mecrası (bu izahatın koşulu) olan epistemolojinin problem çözücü (uygulanabilir

\footnotetext{
${ }^{1}$ Tam da bu nedenle her iki konum da doğru olamaz.
} 
/ müdahale edebilir) olup olmadığg bu bağlamda kökenseldir. Bhaskar'ın felsefe üzerine bir sorusu (2017: 186) epistemolojiye şöyle uyarlanabilir: Eğer epistemoloji gerçekten bilim (gerçekliği bilmek) hakkındaki zorunlu hakikatleri tesis edebilecek itiraz kaldırmaz bir disiplin ise, bu durumda ister misiniz pratikte zorunlu olan şey teoride reddedilmiş olsun? O halde, pratiğiyle çelişen bir teorinin başına gelen (gelecek) olan şey -yavaş bir ölüm-, epistemolojinin de başına gelmiş midir?

Bu tartışmanın yürütülmesi için epistemolojinin bilgi / bilim teorisine dönüşüm sürecinin şafağı olarak görülebilecek olan Immanuel Kant'ın çalışmasının taraflarca nasıl ele alındığının incelenmesi, genel tartışma için bir belirteç niteliğindedir. Micheal Friedman'ın (2015: 22), Kantçı düşüncenin felsefenin bilimle verimli birleşimi olarak görülmesi gerektiği yönlü tespiti, Kant'ın bu çalışmada bir belirteç olarak seçilmesinin gerekçesini aydınlatmaktadır. Felsefe yerine doğrudan epistemoloji yazılması kaydıyla, Friedman'1n esas tespiti olduğu haliyle kabul edilmektedir: "Mevcut felsefi durumumuz sahip olduğu kendine özgü biçimi tamamen, Kant felsefesinin on sekizinci yüzyıla çok iyi uyum sağlamasıyla -dolayısıyla yirminci yüzyıla uyum sağlayamamasıyla- almıştır" (2015: 22). Kant'ın birinci Kritiği konu edinildiğinde bugün "ilgi çekici olmayan bir metafizik kritiği olmak" ile "ilgi çekici fakat tarihi geçmiş bir bilim felsefesi [bilgi/bilim teorisi] olmak" (Baum 1979) arasında bir seçim anı doğmaktadır. İlki, felsefe tarihçisinin yoluyken, ikinci yol bilgi ve bilime ilişkin mevcut problem ağını kavrayabilmek için bir potansiyel taşımaktadır. Çünkü Popperyen çerçeve için, Kant’ın düşüncesi epistemolojinin evrimsel alt çeşitlenişinde yaşamsal ve daha sonrası için 'hayatta kalacak' bir hat oluşturan önemli bir dönüşüm anıyken, Rortyvari bir çerçeveden Kantçı dönüşüm daha baştan, epistemolojinin yavaş ölümünün içerisinde bir alt-ölü-doğumdur. Çünkü Kant, bütün insan deneyiminin, özelde ise bilimin / bilimselliğin temelinde yer alan ve tarihsel olarak değişmeyen bir kavramsal şema arayışındadır. Bu, gerçeklikle ilişki kurmanın olanaklı bütün bağlamlarının olanaklılık koşuluna dair bir aşkınsal arayıştır ve böyle bir olanaklılık koşulu olmadığı için boşunadır. Kant'ın bu boşunalıktan geriye kalan alanda yaptığı / yapabildiği kendi döneminin fiziğinin, içerisinde kendi problemlerini ve çözümlerini formüle edebildikleri 
tarihsel-kavramsal şemayı açığa çıkarmaktır. Bu tespit doğruysa ve Kant'ın bilgi / bilim teorisi sadece tarihsel bir çerçeve ise, bu Kant'ın teorisinin yorumlanışı değil, açıkça reddedilişi anlamına gelecektir.

Meta-problem şudur: İnter-disipliner ve çok-paradigmalı bir bilimle kavranabilir görünen bu dünya, bir kez daha -özellikle de sosyal bilimlerde- Aristotelesler ararken, bilim teorisi 20. ve 21. yüzyıllarda Kant'1nı aramaktadır. Kant, 18. yüzyıl biliminin epistemolojik temelini (şemasını ya da belki de algoritmasını) ortaya çıkarmaya çalışırken, oluşturduğu şemada yanıldı. Fakat kuşatıcı bir bilim teorisi modelinde başarılı oldu. Günümüzde ise aranan ve halen eksik olan şeydir bu: Kuşatıcı bir bilim teorisi. Popper bunun peşindedir, Rorty ise bu arayışın beyhudeliğinin ilanı ile iştigal etmektedir.

O halde sorun, bir kez daha Poppercı anlamda 'avc1 palavrası'nın nasıl ayırt edileceği problemine ve bu probleme dair teorik çerçeveye gelmektedir. Bu ve benzeri vakalardaki karar mekanizmalarında epistemoloji / bilgi teorisi ${ }^{2}$ halen işlevsel bir çark mıdır? Popper için cevap 'evet', Rorty içinse 'hayır'dır. Günümüz felsefe gündemi için ikisi de 'doğru' olamayacağı için, 'hangisi?' sorusunun yanıtına yönelik teorik-tarihsel analiz hem bilim teorisinin kendisinin olanağını ve işlevselliğini ele alan meta-problem alanı hem de bilim teorisinin konu edindiği problem-alanı için 'olası-çözüm'ün anahtarlarından birisidir. Bu 'anahtar' felsefe gündeminin 'şimdi'sinde sınanmak ve dahi kullanılmak üzere geliştirilmiştir.

\section{Tarihsel Arka Plan}

Bilme / bilgi iddialarının meşruluğuna dair problem, felsefeyle (epistemolojiyle) birlikte bilinç seviyesinde tartışılmaya başlandığında filozof, bilgi (daha sonra da bilim) binasının kapı bekçisi oldu (Laudan 1983: 111). Bir disiplin olarak felsefe ise bilim,

\footnotetext{
${ }^{2}$ Türkçe'de yaygın biçimde 'epistemoloji' ve 'bilgi teorisi' terimleri eşanlamlı olarak kullanıldığı gibi 'bilgi teorisi' terimi 'epistemoloji’nin Türkçe karşılığı olarak da kabul edilmektedir. Buna karşın, yaşanan tarihsel değişimi (genel anlamıyla bilginin tanımlanmasından bilginin modellenmesine geçiş) net biçimde gösterebilmek ve adlandırabilmek için epistemoloji ve bilgi teorisi arasındaki nüansın vurgulanması gerekir. Bu nedenle, iki terimin farklı anlamlara işaret etmesine dönük kullanım önerisi benimsenmiş̧ir.
} 
ahlak, sanat ya da din tarafindan ortaya konan bilme iddialarını teminat altında alma ya da bu iddiaların maskesini düşürme teşebbüsü olarak konumlandı. Böylece felsefe (epistemoloji kökenli felsefe), bilgi iddialarının bir araya toplanma yeri olarak kültürün geri kalanı için temel haline geldi. Bunu olanaklı kılan, felsefenin bilginin temellerine vakıf olabildiğinin kabul edilmesidir. İkincil varsayım (ya da temel kabul), bu temellerin bilen-varlık-olarak-insana, bilgiyi mümkün kılan zihinsel süreçlere ya da temsil etkinliğine ilişkin 'felsefi' bir araştırmada bulunabileceğidir. ${ }^{3}$ Bu kabulleri açan kavram (esasında hipotetik kavramsal ağ) 'temsil' çevresinde yapılanmıştır: Öyle ki, "bilmek, zihin dışında olanı kusursuz bir biçimde temsil etmek” iken "bilginin imkânını ve doğasını anlamak zihnin bu tür temsilleri inşa edebilme tarzını anlamaktır” (Rorty 2006: 9, 10). Epistemoloji genel bir temsil teorisi (meta-teori) olduğu ölçüde kültürü, gerçekliği iyi temsil eden, daha az iyi temsil eden ve (iyi temsil etme iddialarına rağmen) hiçbir şekilde temsil etmeyen alanlara ayıracak bir konum açmaktadır.

$\mathrm{Bu}$ kavrayış, temsil / tasarım merkezli olarak Locke - Descartes - Kant bileşiminin bir ürünüdür. Temsil sürecinin "içinde vuku bulduğu ayrı bir kendilik olarak 'zihin' nosyonu” Descartes’tan, "zihinsel süreçlerin anlaşılmasına dayanan 'bilgi teorisi' nosyonu" Locke'dan ve nihayetinde "kültürün geri kalanının iddialarını tasdik ya da reddeden bir saf akıl mahkemesi olarak felsefe nosyonu" ise Kant'tan gelmektedir (Rorty 2006: 10). Bu üçlü, genel epistemoloji tarihinde ve onun da içerisine düştüğü 'dünyayı bilme sorununun' tarihinde özel bir anın şafağına tekabül etmektedir: "Descartes, Locke ve Kant, doğa bilimlerinin başarılarının kültürün sekülerizasyonunu mümkün kıldığı bir dönemde yazmışlardı" (Rorty 2006: 11). Bu dönem, doğa felsefesinin bilgi sorununu, henüz tam adı konmamış olsa da 'doğa bilimi' olarak ${ }^{4}$ Newton'la birlikte çözdüğü inancının entelektüeller arasında hızla yayıldığı dönemdir. $\mathrm{Bu}$ nedenle modern felsefeyi başlatan düşünürler olarak Descartes ve Hobbes (buna

\footnotetext{
3 Özellikle zihinsel süreçlere ilişkin araştırma felsefi olmaktan çıkıp, bilimsel olduğunda (nöro-bilim) epistemolojiye ne olduğu ya da olacağı sorusu, tarihsel sürecin ufkunda doğan önemli bir sorudur.

${ }^{4} \mathrm{Bu}$ ayrışma ancak kilisenin bilim üzerindeki gücü / iktidarı yıkılınca, yani 'bilim ve teoloji arasındaki savaş' kazanıldıktan sonra entelektüel sahneye çıkabilmiştir. Bu da Kant'a gelinciye kadar mümkün olmamıştır (Rorty 2006: 139-140). Bu tespit, Modern Felsefe geleneğinde epistemolojinin öne çıkmasının bir sonucu olarak da değerlendirilebilir.
} 
Francis Bacon'1 da eklemek gerekir) kendi kültürel rollerini “bilim ve teoloji arasındaki savaş" denilen şeye göre konumlamaktaydılar. Diğer taraftan da Locke epistemolojik araştırmaların metafizik ve etik ile ilgili tüm tartışmaları öncelemesi gerektiğinin açık biçimde bilincinde olan ilk kişiydi (Rorty 2006: 139, 142). Bu isimlerle başlayan dönem, Kant'ın Newton Fiziğini model alarak bir bilim olarak metafiziğin kuruluşuna giden yolda "kaçınılmazcasına zorunlu olan" başlangıç sorusunu sorabildiği dönemdir. Diğer bütün bilimler durmadan ilerlerken, bilgeliğin kendisi olmak isteyen ve kehanetine hep başvurulan bu 'bilimde', yani bilimlerin kraliçesi olarak öne sürülen metafizikte tek bir adım atmadan hep aynı yerde dönüp durmak artık gülünçse, soru kendiliğinden doğmaktadır. Acaba Metafizik gibi bir şey olanaklı mıdır? (Kant 2000: 3, 4). Böylece, Kant kendi felsefesinin kaderini, Newton fiziğinin, esasında ise doğa biliminin kaderi ile bağlamaktadır.

Kant'1n ifadesiyle "bir devrim yoluyla" mevcut durumlarına ulaşmış olan matematik ve doğa bilimi örneklerine böylesine bir "üstünlük kazandırmış" olan “düşünme yolunun dönüşümündeki özsel noktaları irdelemek” kendinde bir dikkate değerlik taşırken, "metafizik ile andırımlarının izin verdiği ölçüde (...) onlara öykünme girişiminde bulunmak" denenmeye değerdir (Kant 2015: 24, 25). Bu, epistemolojiden doğan bir şey olarak, eğer olanaklıysa metafiziğin var olabilmesi demektir. Bu olanaklılık sınaması ise epistemoloji merkezlidir. Böylece, felsefe epistemolojiye, epistemoloji de tarihsel gelişimi içerisinde deneysel doğa biliminin 'baykuşuna', yani bilim teorisine dönüşmektedir.

Epistemolojideki Kant merkezli bu dönüşüm, iki boyutludur. İlk boyutu, epistemolojinin sonraki formu olan bilim teorisinin (felsefesinin) Kantçı yönelimini kapsamaktadır. Margaret Masterman'ın sorusu tam da bu boyuta yöneliktir: "Kant'tan güç devşiren bütün bilim felsefecileri, bilimi Newton mekaniği ile eşitleyebilmiş olmasaydı, bilim felsefesi nerede olurdu?" (2017: 99). Bu, başarı kazanmış doğa felsefesinin (biliminin) model alınarak bilginin ve bilmenin standardının belirlenmesi girişimidir ki, epistemolojiden bilim teorisine dönüşümün ana istikametini belirleyen 
birinci boyuttur. İkinci boyut ise, "inanca yer açabilmek için bilgiyi ortadan kaldırmak zorunda kaldım" (Kant 2015: 30) diyebilme noktasından başlayarak Wittgenstein'da "üzerine konuşulamayan konusunda susmalı" (2006: 173) noktasına varan bilgiye ve bilime sınır çekme uğraşının bir alt damarını oluşturan yaklaşımdır.

Epistemoloji git gide bilim felsefesine, teknik bir adlandırmayla da bilgi teorisine (theory of knowldge/science / Erkenntnistheorie: bilim teorisi / bilimsel araştırmanın mantığı) dönüşmesinin bir diğer nedeni, bu dönüşümün konu edindiği bilginin (bilgi yapılarının) özellikle 19. yüzyıldaki kurumsal dönüşümüdür. Bu dönüşümle birlikte, belli bir kuruma değil, öncelikle belli bir disipline bağlllı̆̆n önem kazandığ “profesörlük”ün ortaya çıkması (Mielants 2007: 56-58), disiplinlerin üniversitede (kökeninde Platon'un Akademia'sında) yer alabilmesinin koşulunun bilimsellikleri, yani bilimsel yönteme bağlllıkları ve ürün olarak bilimsel bilgi üretebilirlikleri olarak belirlenmesi söz konusu olmuştur. Artık sembolik olarak doktora derecesine bağl1 (Ph.D) bir felsefe profesörlüğü ve fakat somut ve dahi imgesel olarak 'bilim profesörlüğü’ söz konusudur. Bu dönüşüm Sanayi Devrimi ile birlikte düşünüldüğünde ortaya çıkan manzara şöyledir:

(...) üniversite yapısında da yer alan sanat ve beşeri disiplinler (...) doğa bilimlerinin yeni ve başarılı metodolojisinin iddialarına karşıllı vermekte güçlük çekiyordu. Bilimciler, 'deneysel bilimin başarıları, geleneksel felsefe olmadan da kendini gayet iyi idame ettirdiğini kanıtlamaktadır," gibi ifadeler kullanarak kendilerini felsefeden ayırmaya çalışıyordu: 'Bilimciler felsefeden utanıp sıkılmaya ve deneyler yapacakları köşelerine çekilmeye başladılar' (Mielants 2007: 58).

Nesnedeki bu değişimin felsefede bulduğu yansıma epistemolojinin hem adlandırmasının hem de konumunun değişmesidir. Geleneksel kategorizasyon içerisinde düşünüldüğünde felsefenin bir alt dalı (problem alanı) olarak görülen epistemoloji, bilimi ve bilimsel bilgiyi konu edinen 'bilgi teorisi'ne dönüşerek 19. yüzyıl itibarıyla iç içe geçmiş olan kurumsal ve kültürel konumlanışlar için ilk felsefe (prote philosophia) haline gelmiştir. Böylece kendisinden vazgeçilen, 'utanılan' felsefe epistemoloji üzerinden 'bilimselleşme' yoluna gitmiştir. Söz konusu olan epistemoloji dâhilinde bir 
birleşmedir: Mantık ve empirizm. Bilgi teorisine indirgenmiş felsefe (bilimsel felsefe), kendisini doğrulama bağlamı (context of justification) ile sınırlayan epistemolojidir (bkz. Reichenbach 1936: 143; 1938: 7) ki doğrulama bağlamı daima 'burada ve şimdi'dedir.

Felsefe, ontoloji ve aksiyoloji pahasına epistemolojiye tutunmuş ve bilim dünyasının (Snowcu anlamda Birinci Kültürün [bkz. Snow 2010]) sınırında da olsa 'ben de varım demeye çalışmıştır'. Illk ve belki de tek felsefe olarak epistemolojiye (artık bilgi teorisine demek daha doğrudur) indirgenmiş felsefeyle birlikte, bilgi binasının kapı bekçisi olan filozofa ${ }^{5}$ tali ve fakat ilkinden çok daha fazla tartışma yükü bulunan bir görev daha yüklenmektedir. Açık ifadesini Aguste Comte da bulan 'sosyal fiziği kurma görevi' (Comte 2015: 44, 45), bilim ile bilim-dışını ve ardından bilim ile sahte-bilimi ayırt etme görevini üstlenen bilgi teorisine 'kurucu' bir rol biçmektedir. Yekpare olarak felsefe olmasa da epistemoloji, felsefenin kadim temellendirici, teminat altına alıc ya da maske düşürücü teşebbüs olma misyonunu kendinde taşımaya devam etti. Böylece Kant'1n epistemolojik gölgesi tüm sosyal bilim tartışmalarına düşmüş oldu. Felsefenin 'ben-imajı' (self-image) bu bağlamda halen temellendiricidir. ${ }^{6}$ Neyi bilebileceğimiz ve bildiğimiz şeyi zihnin nasıl işlediğini inceleyerek nasıl daha iyi bilebileceğimiz konusunda daha fazla şey öğrenme projesi olarak epistemoloji (Rorty 2006: 145), 19. yüzyıl itibariyle zihin incelemesini bilişsel bilimlere bırakarak bilginin açığa çıktığı araştırma biçiminin ve onun ürünlerinin çözümlendiği bir hâle -bilgi teorisine- evrildi. Locke ve Descartes ile başlayan ve bir anlamda Kant ile doruğuna ulaşan zihin ve akıl

\footnotetext{
${ }^{5}$ Kant ile birlikte filozof (Rorty'nin ifadesiyle felsefe profesörü) diğer disiplinlerin kendi inceleme nesnelerinin 'yapısının' tayin ettiği meşru sınırlar içinde kalıp kalmadıklarını belirleyebilmeye muktedir bir saf akıl mahkemesinin başkanı olarak konumlandı (Rorty 2006: 146). Bununla birlikte aynı ekolden filizlenen neo-pozitivist bilgi kuramcısının tercihi ve konumlanması "mantıksal çözümlemenin filozofu" olmaktan öte "felsefeyi çözümleyen mantıkçı" olmaktır. Bu çözümlemenin sonucu da bilim / bilim-dışı ve / veya bilim / sahte-bilim ayrımını vereceğinden, bu tevazünün ardında da bir 'mahkeme başkanı' vardır. Ancak hiç dava gelmeyen bir mahkeme olma tehlikesi bakidir.

${ }^{6}$ İkinci kültür içerisinde düşen felsefe geleneğinin imgesi ise "diğer disiplinleri temellendirmek yerine, onları her nasılsa hem tamamlayan hem de içeren bir disiplin olarak felsefe" kavrayışıdır ki bu Hegelciliktir (Rorty 2006: 142, 143). O halde, iki kültür tartışması bağlamında felsefe içinde bir yanda Kantçılık (kendinde-şey kavramı ve dolayısıyla idealizmin baştan çıkarıcı cazibesini reddeden bir Kantçılık) diğer yanda Hegelcilik vardır.
} 
(temsillerin çeşitliliğini birleştirme yetisi olarak akıl) çözümlemesi yerini önce ürün olarak bilginin (önermelerin ve teorilerin) dilsel çözümlenişine, ardından da bir etkinlik olarak doğa biliminin işleyiş biçiminin araştırılmasına -bilim teorisine- bıraktı. Bu süreç, (epistemoloji - bilgi teorisi - bilim teorisi) bir tür evrimsel çeşitlenme olarak görülebilir.

Kant, dönemi itibariyle, Arı Usun Eleştirisi'nde dış dünyadaki nesnel şeylerin varoluşlarının yalnızca inanç / kanı üzerine kabul edilmesini ve nesnel dış dünyaya karşı kuşkuların doyurucu bir tanıtlama ile karşılanamamasını felsefe ve evrensel insan aklı için bir skandal olarak tanımlamıştı (2015: 33, 34). Bu yeni koşullarda epistemoloji bilgi teorisine dönüşürken kısık sesle de olsa yeni bir skandal ilanı söz konusudur: Dünyayı bilme sorununu çözüp, bilgi kuramsal temelde bunun nasıl başarıldı̆̆ını açıklayamamak. Bu açıklayamama durumu daha derindeki bir paradoksa dayanıyordu. Eğer Hume haklıysa, Newton Fiziğinin varoluşu paradoksaldı. Teorik olarak bu fizik olanaklı olmamalıydı, fakat edimsel olarak varolması olanaklılığının kanıtıydı (Popper 2009: XXI, XXII). Kant'la başlayan bu paradoksun üstesinden gelme girişimi bilim felsefesine (bilimsel araştırmanın mantığı araştırmasına) doğru evrildi.

Bilim teorisinin sınırlandırma ayracı problemi dâhilinde bu açıklamayı ve buna bağlı olarak da denetlemeyi yapabilir olduğu, dolaylı yoldan da olsa ilan edildi. Bu ilanı, bir açıklama olarak değil de bir açığa çıkarma, netleştirme, görünür kı1ma biçiminde revize eden neo-pozitivizm için bilgi teorisi ilk ve tek felsefe halini aldı. Bu revizyonla birlikte bilgi teorisi bir modelleme biçimi olarak çözümleme etkinliği ile çerçevelendi. Neo-pozitivizm pozitivist epistemolojiye entegre olan bilimin / bilimsel bilginin tarihsel ve teorik gerekçelendirilmesi görevini üzerinden atarak, bilgi-kuramsal 'uygulama' üzerine yoğunlaşır ve katı bir metafizik reddiyesini benimser. Eğer modern bilim çağında, "bilimlerin kraliçesinin" kendisinin de bir bilim olması gerekiyorsa ki gerekmektedir, o halde felsefe bir bilim değil, bir etkinliktir. Çünkü ilk ve tek felsefe bilgi teorisine dönüşmüş epistemoloji olduğunda felsefe adına geriye kalan ne felsefi önermeler ne teoriler ne de -herhangi- bir sistemdir. Geriye kalan sadece bir yöntemdir; 
felsefenin kendisiyle bilimselleşeceği bir yöntem: Mantıksal çözümleme yöntemi. Buna bağlı olarak da bu girişim genel olarak felsefeyi 20. yüzyılın iki kültürlü dünyasında esasen dili konu alan "bir çözümleme etkinliği olarak" (Ayer 1998: 29, 30; Schlick 1966; Russell 1996: 12; Carnap 1966: 77; Reichenbach 1936: 159; 1968: 305, 308) bilim kültürünün marjına konumlama girişimidir. Diğer bir anlatımla, bu, felsefenin bilimler çağında hayatta kalabilmesi için 'felsefe ile bilim arasında reformist ve neoKantçı bir uzlaşma'dır. Bu uzlaşmayla, epistemolojik dönüş bir çeşitlenmeyle dilsel dönüşe evrilmektedir.

1930'larda bilgi teorisi temelli pozitivizm metafiziği zihinsel evrimin kronik hastalığg olarak görürken (Comte 2015: 175), neo-pozitivizm metafiziği saçmaya indirgeme sonucuna varmaktadır. Bu indirgeme bir kez kabul edildiğinde, felsefede doğru yöntem, "söylenebilir olandan, yani doğa bilimi tümcelerinden -yani felsefeyle hiçbir ilgisi olmayan bir şeyden- başka bir şey söylememek" ve başka biri buna yeltendiğinde, "ona tümcelerindeki belirli imlere hiçbir imlem bağlanmamış olduğunu göstermek”tir. Böylece analitik filozof, çözümleyici bilgi kuramcısına yani “ortalığ 1 biraz temizleyip bilgi yolunu kaplayan saçmalıklardan birazını ortadan kaldırmada bir işçi olarak çalışmak’la yetinen bir 'akademisyen'e dönüşür [evrilir] (Ayer 1998: 9-11, 30, 48, 110; ayrıca bkz. Wittgenstein 2006: 47, 171). Bu dönüşüm, olumlu ya da olumsuz perspektiften ${ }^{7}$ daima değerlendirmeye açık olsa da felsefede gerçekleşen bir [d]evrimden daha azı değildir ve gerçek anlamıyla "bilim felsefesi olarak bilinen disiplini” sonrakilere miras bırakan girişimdir (Reisch 2016: 15). Bu dönüşüm ilk ve tek felsefe olarak bilgi teorisinin (epistemolojinin) akademide dolduracağ 1 yeri tanımlamaya, bu yeri meşrulaştırmaya ve bu yerin devamlılığını sağlamaya yöneliktir. O halde ister akademik felsefenin kurumsallığının tartışılmasından ister felsefenin bir

\footnotetext{
${ }^{7}$ Örneğin, özellikle Ayer ile birlikte mantıksal empirizmin (neo-pozitivizmin) geniş gündeminin dar ama etkin bir bilimsel projeye küçültüldüğü yorumu söz konusudur (Reisch 2016: 19). Bu değişim, felsefenin 'dar bir bilimsel projeye' indirgenmesi olarak kavrandığında özellikle Kıta Avrupası geleneğinden sert eleştirilere maruz kalır. Diğer taraftan ise, analitik gelenekte bilime rağmen bilimi aşma iddiasının artık sürdürülemeyeceği bir çağda felsefenin mecburi istikameti olarak da olumlanabilmektedir. Bu karşıtlığın bir problem alanı olarak çekiciliğinin azalması ile epistemolojinin ölümü ilanları arasındaki ilişki ve bu ilişkinin kendisini gösterdiği toplumsal ve akademik bağlam da ayrıca bir araştırma konusudur.
} 
problemi olarak 'bilgi problemi'nin teorik çerçevelenişinin tartışılmasından olsun (kurumdan teoriye ya da teoriden kuruma), 'epistemoloji ölü müdür?' sorusu tarihsel olarak ertelenemez bir hâl almaktadır.

\section{Bilgi Teorisinin Kantçı Kökenleri: Temsil Fikrini Korumak}

Bilgi teorisi temelinde filozofun akademisyene dönüştüğü sıralarda Popper, neopozitivist tezle uzlaşmaz bir şekilde yalnızca felsefeye özgü ve felsefe için önemli bir yöntemin bulunmadığını savlar. Ona göre, bilgi teorisinin asıl sorunu (mevcut-problemdurumu) bilginin nasıl arttığı ve geliştiği sorunudur ve dil kullanımı veya dil dizgelerini incelemek bilimin gelişimini incelemenin yerini tutamaz (Popper 2012: 28). Bu, dilsel dönüş hattından uzaklaşmak, epistemolojik dönüş hattında kalmak anlamına gelmektedir.

Bunun bir adım ötesinde, Popper, doğruluk (hakikat) için evrensel bir ölçütün var olmadığı konusunda şüpheciler ile aynı fikirdedir. Bunu öne sürmesi ile sınırlandırılacak olursa, şüphecilik bilgi kuramsal açıdan geçerli bir teoridir (Popper 2009: XIX). Popper, epistemoloji (/bilgi teorisi) çerçevesinde Sokrates'i Platon'dan net bir biçimde ayırarak epistemoloji tarihinde bir kökene dönüş yolu açmaktadır. Böylece, kendisini neo-pozitivizmin katili olarak tanıtan Popper (2005: 99), bu 'cinayeti' işlerken epistemoloji tarihinde zamanı daha da geriye almaktadır. Hatta epistemoloji tarihinde bir ayrımdan da öte bir karşıtlık teşhis ederek, bunun üzerine politik bir okumayı da olanaklı kılar. "Bu karşıtlık, iki dünya arasındaki karşıtlıktır - alçakgönüllü, akılcı bir bireycinin dünyasıyla, totaliter bir yarı-tanrının dünyası arasındaki karşıtlık!" (Popper 2010b: 174, 175). Buna ek olarak Popper’a göre, "Sokrates'in (bir çeşit alçakgönüllü bilinemezciliği, akılcı kanıtlara karşı duyduğu kesin ilgiyle birleştirmiş olan) bilim üstüne tavrı, Platon için kavranılamayacak bir tutumdur" (2010b: 380).

Oysa imgesel boyutta, Newton'un Principia'sı yazıldığı tarihten 20. yüzyıla dek pre-Sokratiklerin ve Platon'un araştırma programının 'nihayet' gerçekleşmesi olarak görülmüş ve bu gerçekleşme antiklerin rüyalarının bile ötesine geçmişti. Newton 
Fiziğinin öngörüleri inanılmaz bir kesinlik derecesiyle doğrulanıyorken ve hatta bunlara bağlı olarak Neptün Gezegeni keşfedildiğinde, bu bilgi türü 'şüphesiz' olarak Platoncu ve Aristotelesçi anlamda episteme olarak kabul edildi (Popper 2009: XX, XXI). Oysa Principia'dan yaklaşık yüz yıl sonra ona öykünerek yola çıkan Hume, bu kabulü ciddi bir biçimde şüpheli kılmıştır. Böylece 18. yüzyıl itibarıyla bir yanda yeni filizlenen doğa biliminin teorik başarısı ve buna bağlı olarak bilime aşırı güven yükselirken, diğer yanda epistemoloji çerçevesinde daha önce ifade edilen 'skandal' kendisini göstermiştir. $\mathrm{Bu}$ 'skandalı' ortadan kaldırmaya yönelik ilk epistemolojik girişim Kant'tan gelir: "Anlama yetisi (a priori) [arı doğa biliminin] yasalarını doğadan almaz, onları doğaya buyurur" (2000: 72). Yani, Newton'un teorisi empirik olarak duyumların yardımıyla fenomenlerden toplanmamıştır. Bu teori, aklın doğaya buyurduğu bir şeydir. Ancak bu ne non-empiriktir ne de aklın saf bir yaratımıdır. $\mathrm{Bu}$, empirik veriyi ve onun üzerine teorik bilgiyi olanaklı kılmak için aklın doğaya giydirdiği teorik bir şemadır (Popper 2009: xxii). O halde Newton'un başarısını, yani insanlığın bilgi sorununu nasıl çözdüğünü 'açıklamak' için girişilen araştırma programının nesnesi insan aklının a priori kavramsal yapısı, yani akıl için ortak ve evrensel olan bu 'şema'dır. Kant'ın çalışmasını farklılaştıran ve günümüzde de yönelim olarak geçerli kılan da bu modelleme girişimidir. Kant'ın kendi döneminin biliminin (Öklit - Newton bilimi) epistemolojik temellerine yönelik çalışması, sonrası için bilim teorisi modeli olmuştur. Ancak, Kant'ın oluşturduğu model, bilimsel ilerlemenin ve özelde Einstein'ın teorilerinin açık olarak gösterdiği / yanlışladığı hipotetik unsurlar içermektedir.

Pozitivizm ve özellikle de neo-pozitivizm Kantçı epistemoloji misyonunu üstlenirken yaklaşımsal kökenleri Hume'a ve tümevarımsal mantığa dayanmaktadır. Bu bilgi teorisi içerisinde derin bir tartışma konusu olan olgu önceliklilik / teori önceliklilik ayrımının saflarıdır: Hume mu, Kant mı? Popper'a göre, haklı olan Kant'tır. Tek bir şerhle ki, teori(ler) aklın doğaya buyurduğu ya da üzerine giydirdiği teorik şema(lar) değil, doğaya (gerçekliğe) giydirmeye çalıştığı şeylerdir. Doğa kimi zaman (ve hatta çoğu zaman) bu giydirmeyi tolere etmez: "Onlar aklın ürettiği birer hipotezdir ve zorunlu olarak başarılı değildirler. Doğaya giydirilmeye çalışılan bir hipotez, doğa 
tarafindan bozguna uğratılabilir” (Popper 2009: xxii). O halde Kant epistemolojiyi konumlandırıken isabetli bir hamle yapmış, fakat Newton'un teorisini aklın a priori yapısı olarak çözümlediğinde yanlış bir epistemolojik konuma savrulmuştur. Newton'un imgesel otoritesinin olmadığı etik alanında tanıdığı -ve vazgeçmediği- otonomi, eleştirel akılcı tavrın tam bir yansımasıdır. Bir 'otorite'den gelen buyruğa uymak ya da uymamak kararı tamamen keyfi olmayan, eleştirel zeminde otonom özneye aittir (Popper 2002: 34-35). Oysa epistemolojide Kant'ın savrulduğu konumu yanlışlayacak tarihsel gelişme, Hermann Helmholtz, Ernst Mach, August Föppl ve Henri Poincaré gibi isimlerden geçerek Einstein Devriminin gerçekleşmesiyle kendisini gösterdiğinden, Kant'1 itham etmek de doğru değildir. Hatta Carnap'a değin, hayatına hipotez olarak başlayan bir teorik örgünün doğrulama sayısı arttıkça doğruluk değerinin 1'e yaklaşarak git gide daha muhtemel olduğu ve bir gün kesinlik değerini ilkece alabileceği kavrayışı kendisini korumuştur. Fark, Kant'ın "1" değerini sağlayacak teorik örgüyü aklın verili yapısı olarak konumlamasındadır. Çünkü en fazla doğrulabilirlik derecesine ulaşmak ölçü alındığında, Newton'un teorisi açık ara öndedir (Popper 2009: xxiii). Kant, hatalı bir biçimde bu bağlamsal önde olma durumunu ' 1 ' derecesine varmak olarak kavramıştır.

Popper bu temelde Kant, Sokrates ve Einstein'ı bilgi kuramsal bir çerçevede birleştirir. Yanlışlamacı bilgi teorisi çerçevesi, Kantvari bir biçimde kurguladığı "bilim nasıl olanaklıdır?" sorusunu merkeze alır. Bu bilgi kuramsal modelleme, Einstein'a dayanarak gerçeklik hakkındaki bilimsel bilginin hiçbir zaman kesin olamayacağı (kesin olarak doğrulanamayacağı) ve buna bağlı olarak da bilimsel bilginin geleneksel ve / veya günlük dildeki anlamıyla ya da felsefi kullanımındaki anlamında 'bilgi' olmadığı tespitiyle bu soruya dair hipotetik bir konum açar. Son olarak da Sokratik konumlanışı ufak bir revizyonla bu hipotetik-epistemolojik konumla birleştirir: 'Bildiğim tek şey, tüm bilgimin hipotetik olduğudur' (Popper 2009: xxv, xxvi). Bu konumla birlikte, Popper temel epistemolojik unsur olan doğruluk (truth) ile 'doğruluk üzerine karar verilebilirlik' (decidability) arasında bir ayrım yapar. Buna ek olarak, doğruluk üzerine karar verilebilirlik (verifiability) ile yanlışlık üzerine karar verilebilirliği (falsifiability) 
de ayırır. Newton'unkide dâhil olmak üzere bütün evrensel teoriler kökensel olarak hem açığa çıktıklarında hem de sonrasında ('ölünceye değin') hipotetik ve varsayımsaldırlar. Çünkü doğrulukları gösterilemezdir. Gösterilebilir olan sadece yanlışlıklarıdır (Popper 2009: xxxi). Kant bu varsayımsal konumu fark edememiş olsa da merkezi problemi ustalıkla teşhis edebilmiş̧tir. O halde, Popper'ın bilgi kuramsal çerçevesini oluşturan üçlüde Kant vazgeçilmezdir; tek farkla ki bu Kant'a rağmen Kantçı bir epistemolojik çerçevedir. Çünkü bilginin / bilimin doğru meta-teorisini aramak halen geçerli bir arayış̧ır ve 'temsil' fikrini korumaktadır.

$\mathrm{Bu}$ arayışta Popper'ın ortaya koyduğu teori iki boyutludur: Bilimi konu edinen bir meta-teori ve bilim teorisini (epistemolojiyi) konu edinen meta-meta teori. İlk boyutunda bu teori bilim $^{8} /$ bilimsellik üzerinedir. Popper, teorisini biçimlendiren 'sınırlandırma ayracı'nın, yani bir ayraç / belirteç olarak 'yanlışlanabilirlik' in kendisinin empirik olarak yanlışlanabilir olmadığını kabul eder. Dolayısıyla bu teorinin (ya da sadece sınırlandırma ayracı olarak 'yanlışlanabilirlik'in) empirik-bilimsel bir hipotez olmayıp, felsefi bir hipotez (bir meta-bilim tezi) olduğunu öne sürdüğünde (2009: XXXII), ilk boyut bağlamında teori problematik hale gelir. Çünkü Popper açıkça neopozitivizmin 'yanlış' olduğunu öne sürerken, bu iddiayı doğrulayacak (ya da sınandığında yanlışlamayacak) bir zemin olması gerekmektedir. Ek olarak, Popper, 'yanlışlanabilirlik' ile entegre ve teoride ondan daha fazla önem taşıyan 'eleştirel tavır' söz konusu olduğunda, bu tavrın bir tür 'hata arama tavrı' olduğunu ve bunun "sadece empirik teorilere değil, aynı zamanda ve daha genel olarak felsefi teorilerin eleştirilmesine de uygulandığını" öne sürdüğünde (2009: XXXVI) ilk boyutun problematĭgi ortadan kalkarken, iki boyut ilişkilenmiş olmaktadır. İlk boyutun problematiği ortadan kalkmaktadır, çünkü 'hata arama' Popper'ın teorisinde yanlışlanabilirlik kriteriyle doğrudan bağlıdır ve yanlışlanabilirlik öznel değil, nesnel bir zeminde, yani gerçeklik ile karşı karşıya kalındığında olanaklı ve işlevseldir. Bir bilim teorisinin, bilimin ve / veya bilimselliğin nasıl çalıştığına ve Kantçı anlamda 'nasıl

\footnotetext{
${ }^{8}$ Hatta özelde empirik doğa bilimi üzerinedir.
} 
olanaklı olduğuna' dair hipotezinin sınanması, yani olası yanlışlanma ve dolayısıyla hatanın aranacağı nesnel zemini, teorinin nesnesi olan bilim etkinliğinin, bilimsel teorilerin ve onların tarihinin oluşturduğu 'bilim gerçekliği'dir. Nesnesi gerçek ve empirik olarak ulaş1labilir ise, bu bilim teorisi olarak epistemolojinin sınanabilir bir teori olduğu anlamına gelir. Sınama şudur: Teorinin ortaya koyduğu bilim modeli bir algoritma olarak kabul edilirse, bu algoritmanın çalıştığı biçimiyle bilim mevcut haliyle olanaklı olur muydu? Mevcut haliyle bilim çalışan bir algoritmaya (epistemolojik bir algoritmaya) sahip olduğuna göre, herhangi bir bilim teorisinin (pozitivist, neopozitivist, paradigmatik, realist vb) modellediği algoritma mevcudun olanağını açıklayamıyorsa ya da bu olanağı teorik olarak ortadan kaldırıyorsa, yanlış olan teoridir. Burada söylenebilecek olan bir bilim teorisinin sınandığg ve yanlışlandığı olacaktır. Bu da en azından 'bilim teorisi'nin kategorik olarak, bilimsel bir teoriden farklı olmadığının kabulüdür. Bu çerçeve bir üst dereceye taşınırsa, bu kez bilim teorileri arası ilişki problem olarak ele alınabilir hale gelir: Meta-meta bilim teorisi. Dikkat edilirse bu yönelim, yani felsefenin meta-meta teoriler üretebilir olduğuna dair 'ben-imajı' 'fena halde' Kantçıdır.

\section{Karşıt-Teori, Yeniden Bağlamlanan Ă̆lar: Pragmatizm ve Rölativizm Hayaleti}

Ancak 20. yüzyılda bu ben-imajının hatalı olduğuna dair itirazlar yükseldiğinde, Rorty'nin adlandırmasıyla (2016: 12, 13) post-Kantçı ve dahi anti-Kantçı bir kültür açığa çıkmıştır. Naif bir adlandırmayla Kantçı kültür, modern bilim çağında (Newton'un çağında ve ardından Einstein'ın çağında) felsefenin ne form alacağının tahayyül edilmeye çalışıldığı bir dönemin felsefe kültürüdür. Diğer bir deyişle, Snowcu iki kültür dünyasında birinci kültüre sınırından eklemlenen epistemoloji merkezli felsefenin adıdır. ${ }^{9}$ Oysa bilgiyi problem arz eden ve hakkında bir "teoriye" sahip

\footnotetext{
${ }^{9}$ Belirtilmelidir ki felsefe, Kant sonrasında hep aynı çizgide kalmamıștır. Kant'ı izleyen bir diğer gelenek ise, Fichte, Schelling ve Hegel üzerinden gelişen Alman İdealizmidir. Bu gelenek için epistemoloji ilk felsefe değildir ve Kant'ın numen (noumenon / ding an sich) kavramın odağa alarak ontoloji temelli bir yönelim benimsemiştir. Ancak Rorty'nin iddiası, Kanţ̧ı felsefe resminin esas olarak Hegel sonrası
} 
olunması gereken bir şey olarak düşünmenin, bir temsiller toplamı olarak bilgi görüşünün ürünü olduğu savında olan post-Kantçı yaklaşım "bir temsiller toplamı olarak bilgi görüşü"ne saldırır. Temele, bu şekilde düşünmenin bir "tercihe bağll" olduğunu ve dolayısıyla epistemolojinin de tercihe bağlı olduğu fikri alınır (Rorty 2006: 144). Ortada bir fark olduğu açıktır ve bu fark hem felsefe (epistemoloji) - bilim ilişkisinden hem de bir üst derecede, meta konumdan felsefe - epistemoloji - bilim ilişkine dair felsefe-içi bir çeşitlenmedir.

Doğruluğun ve dolayısıyla bilginin, insanla insani olmayan gerçeklik arasında bir etkileşim meselesi olmasıyla, kişiler arası bir 'sohbet' meselesi olması arasında bir fark vardır. Kökensel olarak Sofist-epistemolojik konumlanışta temellenen bu fark, bilginin gücünü itiraz edilemezlikte görür. İtiraz edilemezliğin muhatabı ve faili öznedir. Buna göre ileri sürülen herhangi bir bilgi iddiası, önermenin referansta bulunduğu nesneye göre değil, bu önermeye rasyonel bir biçimde itiraz edilemezlik kriteriyle değerlendirilir. Bu fark, bilginin önermelerle kurulan bir ilişki olarak ya da önermelerin referansta bulundukları nesnelerle ayrıcalıklı ilişkileri olarak kavranması arasında açığa çıkar. Geleneksel itiraz, bilginin önermeler arası bir ilişki olarak kavranması durumunda sonsuz bir geriye gidişin kaçınılmazlığı üzerinden yükselir. Ancak, insanlar bir kez tatmin olduktan sonra daha fazla devam etmek her ne kadar olanaklı olsa da gereksizdir (ve hatta 'saçma'dır). İkinci durumda ise, önermenin ötesine geçmek ve nesneden (gerçeklikten) etkilenen herkes için şüphe etme ya da alternatif görmenin imkânsızlaşması amaçlanır. "Bu noktaya ulaşmak bilginin temellerine ulaşmak demektir" ki, epistemoloji bu imkâna ve bu imkânın soruşturulması demektir (Rorty 2006: 166, 167).

$\mathrm{Bu}$ çalışmanın hipotetik şeması hatırlanacak olursa, temsillerin gerçek ya da gerçek dışı, doğru ya da yanlış, sadık ya da sadakatsiz şekilde yargılanması söz konusu

benimsendiği yönündedir. Diğer bir deyişle felsefe Hegel sonrası (sistem kurma girişimine son verdiği zaman) Kant'a dönüş yaşamıştır. Böylece felsefe bu yeni dünyada profesyonelleşmiş ve diğer disiplinlerin inceleme nesneleri ve görevlerinden açık bir şekilde ayırt edilir olmuştur (bkz. Rorty 2006: 140, 141). Diğer taraftan Heidegger'in dile getirdiği, Birinci Kritik'in doğa bilimsel bilginin teorisi olmaya yönelik bir epistemoloji olmadığı, bir ontoloji olduğu yönlü itirazı da halen caridir. 
olduğunda 'dünya'nın ortaya çıkması ve doğruluk / bilgi probleminin temsilin alternatif tarzlarının açığa çıkmasıyla doğması belirlenimleri bu bağlamda aydınlatıcıdır. Çünkü Rorty'ye göre, Platon'dan Kant'a dek epistemoloji bu şema üzerinden okunabilir niteliktedir: Bilginin temellerine ulaşmak, Platon'da "duyulardan kaçarak ve akıl fakültesini -ruhun gözü- varlı̆̆ın dünyasına açmak”, Descartes’ta “zihnin gözünü karışı iç temsillerden açık ve seçik olanlara çevirmek", Locke'da ise duyulara tekil olarak verili olanı bizi etkilemesi gereken şey olarak görmektir (Rorty 2006: 167). Her durumda, temsili, temsilin ötesindeki gerçeklik üzerinden değerlendirmek söz konusudur. Epistemoloji tarihindeki değişim, epistemolojik odağın görünüş-gerçeklik ayrımından, iç - dış (zihnin içi ve dış dünya) ayrımına doğru kaymasındadır. Her iki odakta da temsillerin bir kısmını gerçekliğe ilişkin kılarak ayrıcalıklı tutacak ve geri kalanı görünüşler olarak bir kenara bırakmayı olanaklı kılacak ölçüt arayışı kendisini göstermektedir. Bir post-Kantçı için epistemoloji, bu ölçüt arayışının ve tespitinin kendisi değil, olanaklı görülmüş yollarından birisidir. Diğer bir deyişle bu arayışın kendisi ve biçimi tercihe bağlıdır. Rorty'nin tercihi pragmatik ölçüttür. Pragmatik ölçüt baz alındığında epistemoloji ile iştigal etmek ve felsefeyi evrensel bilgi olanağında temellendirmeye çalışmak, "eski sloganları ve stratejileri, pratik yararları çok geride kaldıktan sonra canlı tutmaya çalışan duygusal bir nostalji”yi (Rorty 1999a: 9) sahiplenmekten ötesi değildir. O kadar ki, Popper'ın da içinde yer aldığı Anglo-Sakson geleneğin (analitik felsefe) yaptığı da Kant üzerinden (onun yönelimini koruyarak) özünde Locke'u güncelleştirmektir (Rorty 2006: 169). Diğer bir deyişle, epistemolojinin aradığı (tesis etmeye çalıştı̆̆ı), üzerlerine bilginin ve / veya bilimin inşa edildiği ayrıcalıklı temsiller, bilim teorisinde protokol önermelere dönüşürken (teori yüklülük tartışmasını açığa çıkaracak biçimde), bilim teorisi epistemoloji tarihinde Locke'u çağırmış ve bir kez daha 'bilgi' söz konusu olduğunda empirik önermelerin merkeziliği fikrini parlatmıştır. Oysa karşıt teze göre "mütekabiliyet olarak doğruluk", "temsilin tamlığı ve kusursuzluğu olarak bilgi" ve en önemlisi de "müstakil disiplinlerin meta eleştirisi olarak Kantçı felsefe nosyonu" gerçek-dışı problemler ve çözümler üreten, tercihe bağlı bir felsefe biçiminden ibarettir ve terk edilebilir. Hatta terk edilmiştir: 
“(...) analitik epistemoloji (yani bilim felsefesi) giderek tarihselci ve giderek daha az 'mantıksal' (Hanson, Kuhn, Harré ve Hesse'de olduğu gibi) hale geldi' (Rorty 2006: 174-175).

Post-Kantç1 meta bir konumdan incelendiğinde analitik epistemoloji tarihinin kendi problemlerini çözemeyen teorilerden oluşmasının nedeninin, hepsinin açık veya örtük olarak bağlılığını koruduğu Kantçı damar olduğu görülmektedir. Buna karşın, ayrıcalıklı temsiller (sentetik a priori / idea innata / basit idealar / protokol önermeler / teorik önermeler vb) yani epistemik ayrıcalık fikrinden vazgeçildiğinde, analitik epistemolojide gerçekleştirilen analizin ne sunduğu gayet muğlâk kalmaktadır. Diğer taraftan, aşkınsal zihin yetilerine bağlı zorunlu kavramlara / görülere bağlı 'kurallar'a göre 'kurulmuş' katı olgular (hard facts) ile herhangi bir a priori kurala göre kurulmamış yumuşak nesneler (soft objects) arasındaki fark da Kant'ın dil oyununa bağlı olduğu oranda geçerlidir (Rorty 1997e: 83). Hegel'in 'kuralların' tarihselliğini göstermesinin ötesinde, bunların olumsallığının da açığa çıkması Kant'ın sınırının ötesindedir. Rorty'nin Donald Davidson'dan aktardığı ve benimsediği “nedensellik bir tanımlama altında değildir, fakat açıklama öyledir" (1997e: 81) tespiti, olguları hibrid hale getirmektedir. Çünkü olgular daima teori (yani açıklama) yüklüdürler ve teoriler de olumsal ve yapaydırlar. "Dünya orada, dışarıda"dır, fakat "hakikat orada dışarıda" değildir ve dile bağlı oldukları oranda insan yaratısıdırlar (Rorty 1995: 26). İnsan yaratısının da a priori belirlenmiş nesnel bir şablonu, çerçevesi yoktur. Böylece, Kantçı akıl kategorileri bir teorinin (dünyayı görme ve açıklama biçiminin) olumsal kavramlarına dönüştürüldüğünde, esasında Kant terk edilmiş olmaktadır. Katı olgularla yumuşak nesneler arasındaki fark, onları böyle tanımlayan teoriler ve bu teorilerin varlık kazandıkları kurumlar arasındaki farkta yatmaktadır ki bu fark da hiçbir zaman a prirori değildir. Hatta bu fark ya da ayrım ontolojik, metodolojik veya epistemolojik de değildir (Rorty 1997e: 84). Bu terk edişte idealizme düşmeme manevrası olarak da "kaba fiziksel direncin varlı̆g"nın mutlak kabulü hamlesi gelmektedir; ancak bir uyarıyla: "dilsel olmayan bu kaba etki olgulara, önermelerin doğruluklarına transfer edilemez" (Rorty 1997e: 81). 
Bu kaba etki, Rorty'nin 'inançlar ve istekler ağı olarak zihin'le temas halindedir. $\mathrm{Bu}$ temas, ağda yeni inançların ya da isteklerin doğmasının önemli bir nedenidir. Ancak bu noktadan sonrasında birer dil oyunu ve hatta dil oyunları örüntüsü olarak yapılanmış ağda oluşacak “çelişkiler” ve / veya "gerilimler” (tensions) olası birkaç yolla ortadan kaldırılır ya da sönümlenir. Örneğin, eski bir inanç ya da istek terk edilebilir ya da "bütünlüklü bir sürü yeni inanç ve istek rahatsız edici davetsiz misafiri sarmalamak ve eski inançların onun üzerinde ve onun da eski inançlar üzerinde yarattığı baskıyı azaltmak için yaratılabilir”. Veyahut da bir önceki ağ tamamen sökülüp, silinebilir. Bu durumda bazı sözcüklerin (örneğin 'filojiston' ya da 'doğal haraket' gibi) kullanıldığı tümcelere karşı tepki vermeyi bırakabiliriz (Rorty 1997f: 93). Motivasyonundan bağımsız bir biçimde araştırma / sorgulama durumunda gerçekleşen şey de ağa yeni inançların eklenmesi ve / veya buna bağlı olarak da ağın yeniden yapılandırılmasıdır. $\mathrm{Bu}$ süreç -sabit- bir algoritmaya bağlı değildir; dolayısıyla epistemoloji bir kez daha boşa düşmektedir. Yerleşik dil oyununun [Wittgenstein] olağan bir parçası olmadığı için ilk bakışta yanlış görünen ve bu nedenle kullanılmaya başlandıkları sürecin başında sadece birer 'metafor' olan [Davidson + Hesse] ifadelerin bir kısmının literal / olağan doğruluk adayları olmak anlamında dil oyununu dönüştürmekte 'başarılı' olmaları söz konusudur (Rorty 1997g: 124). Rorty bu ve benzeri süreclere "yeniden-bağlamlama" (recontextualization) adını verirken (1997f: 94), Wittgenstein, Davidson, Hesse'nin oluşturduğu teorik arka planda Kuhn'un paradigması ile Quine'ın bilgi ağını birleştirmekte ve Feyerabend'in tarihselliğini benimsemektedir. Ama esasında bu arka plan ve üçlüyle birlikte yaptığı şey, "doğası gereği imtiyazlı / seçkin bir bağlamın var olmadığını" söyleyerek (1997f: 96) Kant'ın a priori kategorik akıl arkitektoniğini, sürekli yeniden-bağlamlanabilir (evrilebilir) hale getirmektir. Yeniden-bağlamlanma tarihsellikle (koşullulukla) iç içe olsa da üç unsurlu bir mekanizmadan söz edilebilmektedir. Rorty, yeniden-bağlamlanma ile sonuçlanan üç yolu, 'algı', 'çıkarım' ve 'metafor' olarak belirlediğinde (1999a: 12), 'algı' ve ‘çıkarım'ı mevcut ağın yeniden örülmesinin unsurları, 'metafor'un ise ağın eski ipliklerinin bir kısmı yeniden kullanılsa da tamamen farklı düğüm noktalarından oluşan 'yeni bir ağ' meydana getirme yolu 
olduğunun altını çizer. Bu nedenle, biliş ve / veya kavrayış ya da 'doğru bilgiyi' edinmek her zaman için verinin mevcut olan bir şemaya uyması değildir. Diğer bir ifadeyle, bilmek ve / veya kavramak mantıksal uzamın empirik olarak doldurulmasının ötesine geçer. Rorty'nin ifadesiyle (1999a: 12, 13), metafor, o mantıksal uzamın ötesinden bir ses olarak, tüm uzamı dönüştürebilir. Böylece, sonradan başka filozoflarda ‘dilin mantıksal yapısı' ve / veya 'mantıksal uzam'a, hatta 'bilimsel araştırmanın mantığına/algoritmasına' dönüşse de biçimsel ve tarih-dışı bir şema olarak kabul edilmeyi sürdüren Kant'ın akıl arkitektoniği, gerçekliği kavrayış biçiminin kaynağına metafor yerleştirildiğinde (Rorty 1999a: 12) tamamen açık-uçlu hale dönüştürülmektedir.

Rorty'nin 'algı' - 'çıkarım' - 'metafor' ilişkiselliğini ifade edişi, üslubunun Kıta Avrupası Felsefe geleneğine en yakın olduğu yerdedir. Dikkat edilecek olursa, bu ilişkiselliği kendi analitik ve pragmatik arka-planıyla Heidegger ve Derrida arasında bağlantılar bulduğu metinlerde kurmaktadır (bkz. Rorty: 1999). Ancak, Rorty'nin bu anlatımı rahatlıkla (ve tesadüfi olmayan bir biçimde) Kuhncu bir dile tercüme edilebilir: Algı ve çıkarım olağan-bilim döneminde, yani baskın ve belirleyici bir paradigma mevcut ve aktifken işlevsel olarak çalışır. Metafor, ilk duyulduğunda / kullanıldığında mevcut paradigmanın dışından, olası alternatif-paradigmadan gelmektedir ve mevcut durum için 'yanlış' veya 'anlamsız'dır (Aristoteles Paradigması bağlamında 'Gravitasyon' gibi). Çünkü, mevcut paradigmayla tamamen uyumsuzdur; yani mevcut paradigmaya ait bir yap-boz parçası değildir. İki paradigmaya da dışarıdan bakabilen ve kendisi de paradigmatik olmayan hiçbir konum yoksa, bu geçişin (Kuhn'un ifadesiyle 'bilim insanının araştırmayla bağlı olduğu dünyayı değiştiren' paradigmalar arası geçişin) aşkınsal ve dolayısıyla koşulsuz olarak (her zaman her yerde geçişi koşullayan algoritma arayışı) açıklanabilir olup olmadığı öne çıkan düğüm noktasıdır. Sürekli yeniden-bağlamlanabilirlik, diğer deyişle, açık uçluluk kabulü, Kant’ı terk etmek üzere bir ayağı 'dışarı' atmaktır. 
İkinci ayağın da bu ilk adımı takip etmesi kaçınılmazdır. Çünkü Kant’ın terk edilmesi, metafiziğe veya epistemolojiye ihtiyacı olmayan, 'hakikat' ile 'gerekçelendirme' arasındaki yarığın "izole edilmiş bir tür doğal ya da aşkın-kültürel rasyonalite" ile kapatılamayacağının da kabul edilmesidir (Rorty 1997b: 22, 23). Çünkü rasyonalite de ağ içerisinde sürekli yeniden bağlamlanabilir bir kavramdır. Bu kabul, elde olan tek ölçütün "bizim için iyi olan" seçenek ile potansiyel olarak daha iyi olan seçenek arasında seçim yaparken başvurulacak pragmatik ölçütün kabulünü eş zamanlı olarak getirecektir. $\mathrm{Bu}$ farklılaşma, "gerekçelendirilebilir doğru kanı"dan "gerekçelendirilmiş iddia edilebilirlik"e geçiştedir. 'Bilgi' ile 'kanı' arasındaki tek gerçek fark özneler-arası uzlaşı sağlama sürecinin göreli olarak kolay olduğu durumlarla zor olduğu durumlar arasındaki farka tekabül eder (Rorty 1997b: 23). Yani bilime dahil olmak üzere ortada tarihsel olmayan, 'epistemolojik' ve her durumda sonuç veren bir algoritma, bir mantık ya da bir şablon (model) yoktur. Dolayısıyla herhangi bir çalışmayı, yönelimi, kültürü 'bilgi' temelinde kritik etmeye yarayacak bir ayraç da yoktur.

Bu durumda da bilim çalışmaları içerisinde 'bilimi' kavrayabilecek olanaklı yol şudur: Gerçekliğe dair verinin girdi olarak nasıl oluştuğu ve işlendiğine dair "nedensel mekanizmaları kuşatacak bir psikofizyoloji” / nöro-fizyoloji ile entegre edilmiş bilim sosyolojisi ve tarihi (Rorty 2006: 232). İlki gerçeklikle temasın psiko-fizyolojik nedensel mekanizmasını (donanımı ve bilişsel süreci) kavramayı sağlarken, ikinci grup (bilim sosyolojisi ve tarihi) gözlem önermelerinin teoriler kurar ve yıkarken nasıl kullanıldığına dair sosyo-tarihsel vaka incelemesiyle sosyal bir fenomen olarak bilimi (sosyal süreci) daha açık kılmaya çalışır.

Bu süreçte epistemolojinin yapabileceği bir şey yoktur. Rorty için epistemolojinin geri çekilmesinin yarattığı boşluğu doldurma girişimi de hatalıdır. Bunun yerine ikame edilebilecek tek şey, hermeneutik bilim tarihi ve sosyolojisidir (2006: 233). Böylece, bilim (ya da bilme süreci) yine bilimin konusu (Nöro-bilim, fizyoloji [bilimin doğa bilimi], psikoloji, bilim sosyolojisi, bilim tarihi [bilimin sosyal bilimi]) kılınırken, bu 
alanda epistemolojiden geriye ne kaldıysa geri çekilmektedir. Hem bilginin doğasını hem de geride kalan boşluğun kendisini inceleyecek araştırma çerçevesi sosyo-tarihsel bir anlatımdır (Rorty 1997b: 24). Bu alana ilişkin bir araştırmaya girişebilecek yegâne aday, Rorty'nin de sıklıkla andığı ve metinlerine sinmiş olan Thomas Kuhn'un hermeneutikle örülmüş 'paradigmatik bilim teorisi'dir. O kadar ki, Rorty, kendisini Kuhn'un 'pragmatist dostu' olarak tanımlarken, Kuhn'u bilim / bilim-dışı ayrımının yumuşaklığını gösterdiği için (ve tabii ki eşzamalnlı olarak nesnel / öznel ayrımının keskinliğini ortadan kaldırdığı için) tebrik etmektedir. Rorty'nin pragmatizmi, kendisinin de sahiplendiği bir isimle- "sol kanat Kuhnculuk", yani nesnelliği "zora dayalı olmayan uzlaşı" olarak tanımlamaktır (1997c: 38). Bir kez bu kabul edilirse, yani, Kuhn'un yaptığı gibi bilimin pradigma üzerinde genel bir uzlaşı ile icra edilen bir meslek (paradigmatik aidiyetin belirleyici olduğu bir grup etkinliği) olduğu veya aynı anlama gelecek biçimde 'nesnelliğin' genel bir uzlaşı olduğunun görülmesi, Rorty'nin ifadesi ile (1997c: 38) "rölativizm hayaletinin yükseliş̧" için yeterli olacaktır. Bu yükseliş, yöntemden arınmış pragmatizm ile derinliklerinden arınmış kıta felsefesinin bir araya gelişidir (Rorty 1997d: 77). Bu bağlamda, Rorty'ye göre, 20. yüzyılda felsefenin karşılaşma alanı, idealizm / fizikalizm karşıtlığının yerini alan ve realizm / anti-realizm tartışmasının da ötesine geçen pragmatizm / anti-pragmatizm mücadelesi tarafindan belirlenmektedir (1997h: 149). Bu mücadele, felsefenin devrim sürecinde (evet, bu teze göre felsefede de Kuhn'un bilime özgü olmak üzere bilimin tarihinde tespit ettiği gibi devrimler vardır (bkz. Rorty 1999c:109, 110) ) vuku bulmaktadır. Yaklaşık yüz atmış yıllık devrim sürecinde (ki esasen Kuhn'un modeli genişletilecekse bu sürece felsefede kriz dönemi demek daha doğrudur) 'mümkün bütün bilginin nihai temelinin ilkelerine' dair araştırmanın beyhudeliğine dair kavrayış güçlenmektedir. Bu anlamda, epistemoloji artık eskinin söz dağarı olarak geride kalmakta ve epistemolojiye ait terimler ve / veya sözcükler yeniden-bağlamlanmaktadırlar. Bu süreci bir ölümkalım mücadelesi biçiminde tek ciddiye alanlar ise filozofların bir kısmıdır. Geri kalan dünya için, hatta bilim için ortada ciddi bir problem yoktur. Rorty'nin Freud göndergesi (1999c: 108) tam da buna ilişkindir: 
Tanrı ile kişisel, neredeyse ebeveynlik ilişkisi olduğunu iddia eden peygamberler, Tanrı'nın bizler için de en az kendileri için olduğu kadar kaçınılmaz olduğunu söylerler. Ancak Freud'un öne sürdüğü gibi, bu tür peygamberler, kendilerine özgü problemlerini evrenselleştirmek yoluyla mazur göstermeye çalışmaktadırlar: kendi bezdirici ve huzursuz edici ebeveynlerinin herkesin ebeveyni olduğunu hayal ederler.

Epistemologlar da benzer bir şey yaparak, kendilerine has problemlerin evrenselliği hayali ile var olmuşlardır. Oysa başta bilim olmak üzere kendi dışlarında kalanlar için böyle bir durum söz konusu değildir. Diğer bir deyişle, kökenleri çok daha geriye gitse de, Kant, epistemologlar ve dahi bilim teorisyenleri için Freudcu anlamda evrenselleştirmeye çalıştıkları bir ebeveyn figürüdür.

\section{Epistemolojik Olarak Kant'tan Pragmatizm Çıkar mı? / Pragmatizm Pragmatizme Karşı}

Karşıt-tezin ironisi, epistemolojiyi geride bırakırken yine de bilimle yüzleşmek zorunda kalmasında yatmaktadır. Her ne kadar "katı olgular / yumuşak değerler", “nesnellik / öznellik” ayrımlarını ve dahi yöntemde somutlaşmış rasyonalite ve gerçeklikle yüz yüze gelme yeri olarak bilim kavrayışını tesis eden söz dağarını terk etme çağrısı yapsa da (Rorty 1997c: 35-36) doğa bilimini mevcut haliyle (başarısıyla) yeniden tasvir edecek bir yol da aramaktadır. Diğer bir deyişle onun sorunu çalışan bilimle değil, bilimin kültür içerisinde tarif edilme (kavranma) biçimiyle ilgilidir. Bilim insanlarının diğer insanlara nazaran daha "nesnel”, "yöntemli”, “mantıklı" ya da "[gerçekliğe uygunluk anlamında] hakikati daha fazla savunan" insanlar olmadıkları ve fakat onların geliştirdikleri ve içerisinde çalıştıkları kurumların övülmesi ve kültürün geri kalanı için model alınması gerektiği söylendiğinde (Rorty 1997c: 39), bu kurumların nesnel, yöntemli, mantıklı terimleriyle karş1lanamayacak mekanizmasının ne olduğunun sorulması halen meşrudur. Çünkü, Rorty'nin bu kurumlarda gördüğü övülesi nitelik (1997c: 39), fikirler ve teoriler çokluğunun "özgür ve açık karşılaşma” mekanını kurabilmeleridir. Fakat Rorty'nin göremediği -ya da kısmen görmezden geldiği- esas mekanizma ilgili kurumlarda bu fikir / teori çeşitlenmesinin nasıl elendiğine dairdir. Soru, 'bilim / bilim insanları teorileri nasıl kuruyorlar ve 
savunuyorlar?" biçiminde kodlanmaktan ziyade, 'yanlış teorileri nasıl eliyorlar?' biçiminde kodlandığında “özgür ve açık karşılaşma”nın bu kurumların övülesi niteliği için eksik bir tespit olduğu görülecektir. Öte yandan da bilimin nitelenmesine dair soru, kendisini “bilimin neyde -ve neden- 'bu kadar' başarılı olduğu' sorusu olarak dayatır. $\mathrm{Bu}$ soru, Rorty’nin kavrayışı bağlamında, onun metaforunu ona karşı kullanacak olursak, epistemolojinin hayaletinden gelmektedir.

Rorty’nin yanıtı, doğa biliminin ${ }^{10}$ "doğanın kestirim ve kontrol edilmesinde" başarılı olduğu yönündedir (2006: 347). Kant'ın -değişmez ve evrensel sandığ1kategorileri gibi, içerisinde düşündüğümüz çerçeveler ya da araştırma yapıları esasında şekillendirilebilir / uyarlanabilir şeylerdir. Onların uyarlanmalarının ya da tamamen değiştirilmelerinin tek nedeni ise, bu değişimin -Rorty'nin örneğiyle Aristoteles'in zaman-mekân kavrayışından Newton'unkine geçişin- şeyleri manipüle etmeye daha hazır hale getirmesidir (1999b: 30). Rorty'nin diğer bir ifadesiyle, "Newton'un kelimeleri gerçekliğe daha iyi tekabül ettikleri için değil, sadece gerçeklikle başa çıkmamızı daha iyi sağladıkları için Aristoteles'ten daha iyi olduğu bir kez kabul edilirse, bilimi dinden ya da politikadan ayıracak hiçbir şey yok demektir” (2006: 275). 'Gerçeklikle başa çıkmak' Rortyci anlamda 'anti-temsilci' (antirepresentationalist) yaklaşımda bilginin oynadığı roldür (Rorty 1997: 1) ve mevcut haliyle "bilim (...) niçin güçlü yeni tahmin ve kontrol teknikleri üretir?” sorusuna verilecek en iyi cevabın ne olduğunun bilinmediği durumda (Rorty 2006: 347) elde kalan yegâne yanıttır. O halde, "beşerî varlığı objektivize etmeye adanmış" epistemoloji (Rorty 2006: 387) geçmişte bırakıldığında ya da sınırlandırıldığında geriye pragmatizm kalmaktadır.

$\mathrm{Bu}$ konumda realistlerin pragmatistlere yakıştırdıkları 'görelilik / rölativizm' yaftası üç anlamı içerisinde analiz edilmekte ve her inancın bir diğeri kadar iyi olduğu kabulünü ve 'doğru' teriminin her farklı tanımına göre ilkece tanım sayısı kadar fazla gerekçelendirme (doğrulama) prosedürü olduğu kabulünü esas alan iki görelilik

${ }^{10}$ Rorty, doğa bilimleri ile beşeri bilimleri epistemolojik ve / veya metafizik bir temelde değil, amaçlarında ayırır. Dolayısıyla öngörmek ve kontrol etmek doğa bilimlerinin amacıdır; beşeri bilimlerin değil (Rorty 1997c: 40). 
çerçevesi reddedilmektedir. Rorty'ye göre pragmatizmin uzlaşabileceği yegâne görelilik, hakikat ya da rasyonalite hakkında verili bir topluluğun / toplumun tanıdık gerekçelendirme / doğrulama / sınama prosedürleri tanımlamalarından bağımsız konuşulamayacağını dile getiren türde olanıdır (1997b: 23). Bu tam da Thomas Kuhn'un paradigmalarını akla getiren görelilik türüdür. Thomas Kuhn'un da başını ağrıtan soru burada da yankılanmaktadır: Paradigmatik devrimde her şey değişiyorsa, 'ilerleme'den söz edilebilir mi? Ya da halef paradigma neden ve neyde selef paradigmadan daha 'iyi'dir? Bu soru(lar) 'bilimin amacı nedir ve bu amac1 gerçekleştirdiğini nasıl bilebiliriz?' sorusunun muadilidir(ler). Rorty’nin, “bir araştırmanın amacı zora dayanmayan uzlaşı ile birlikte tolere edilebilir anlaşmazlığın uygun bir karışımını elde etmek"tir (1997c: 41) ve bu 'uygun' miktar deneme yanılma ile belirlenir (1997c: 41) biçiminde dile getirdiği 'pragmatist' tasvir epistemolojinin hayaletvari sorularını def etmeye yetmez. Objektivizm eleştirisi pandoranın kutusunun açılmasıdır. Birinci düzeyde bilimin amacının ne olduğu sorusuyla ikinci düzeyde (meta-düzey) bilimi konu edinen bilim teorisinin (epistemolojinin) amacının ne olduğu sorusu bu kutu açıkken ayrı ayrı cevaplanamaz.

Bilimin, gerçekleştirebildiği için onu ayrıcalıklı kılan açık amacı, gözlem düzeyinde sahip olduğu öngörücü (kestirimci) ve onun doğrudan çıktısı olan manipülatif güçtür. Bilimin ayrıcı gücünü burada gören pragmatistler için bu neredeyse kendinden açıktır. Diğer taraftan bilimin örtük amacı, hakikate olanaklı olduğu ölçüde yaklaşmaktır ki realistler için bilimin bundan başka asli bir amacı yoktur. Bilimin ayırt edici başarısı, hakikate git gide daha fazla yaklaşan açıklamalar üretebilmesindedir. Ancak bir pragmatist için, öngörü gücünün sınanabilir başarısı ve ona bağlı olarak da gerçekliğe müdahale edebilme gücü bir ölçüt olarak alınmazsa, alternatif açıklamalar arasında karşılaştırma yapılamaz. Dolayısıyla, çeşitlenmiş teoriler arasında bir eleme yapılamaz.

Meta düzeyde söz konusu edilen bilim teorileri olduğunda aynı soru tekrarlanabilir niteliktedir: Bir bilim teorisinin amacı nedir? Gözlem düzeyinde, bilimin 
teorik ve kurumsal yönünü öngörmek ve dahi müdahalede bulunmak üzere bilim politikalarına doğrudan etki etmek mi yoksa 'bilim' adı verilmiş etkinliğin özellikle sosyal ve tarihsel mecradaki konumunu (çünkü ontolojik olarak bu mecrada var olmuştur) ve değişimini açıklamak mı?

Her iki düzeyde de soru aynı yere bağlanmaktadır. Çeşitlenmiş ve dolayısıyla birbirlerinin alternatifleri halini almış açıklama modelleri arasında açıklayıcı güç bakımından yapılacak bir karşılaştırmada karar neye göre verilecektir? Bu bağlamdan bakıldığında açıklamalar, kendi başlarına düşünüldüğünde gerçekliğe ilişkin alternatif temsillerdir. Alternatif temsillerin açığa çıktı̆̆ı (çoğaldığı) dönemde gerçeklik probleminin belirginleşmesi (hangi açıklamanın koyutladığ1 'gerçeklik' gerçektir?) önemli bir göstergedir.

Epistemolojik olarak teori öncelikli konum (hipotez yoksa olgu [tespiti] yok) (Popper 2015: 16-19, 140, 141), idealist bir savrulmay1 da beraberinde getirebilmektedir. Böylece epistemoloji içerisinde eş-ölçülemezlik probleminin neden rasyonalizm - irrasyonalizm sarkacına sıkışıı̆ı da aydınlanmaktadır: Örtük idealist ontoloji fona yerleştiğinde sahne alan epistemolojik tartışma, olgu tespitinin (ve bunu olanaklı kılan paradigmatik / hipotetik bakış biçiminin / Kant'nn akıl arkitektoniği) ötesine geçemediğinden ve fakat idealist ontolojiye düşmekten de kaçındığından kısır döngüye girmektedir. Bu döngüden çıkışın tek yolu, pragmatik ölçütü (Hackingci ve dahi Poppercı 'müdahale'yi) tek ontolojik ölçüt ve bunun yanı sıra ilerleme ölçütü olarak kabul etmekten geçmektedir. $\mathrm{Bu}$ daha temelde, "bilgi ile insan gücü eş anlamlıdır" ve "bilimlerin gerçek ve doğru hedefi, yeni keşifler ve zenginliklerle insan yaşamını donatmaktır" diyen Francis Bacon'ın (2012: 120,157) tespitini yinelemek anlamına gelmektedir. Eğer bilgi ile insan gücü eş anlamlıysa, gücün artması bilginin arttığının açık göstergesidir. Ancak bu, tam da bilimi epistemolojik boyutta öngörü gücü ile sınırlamak demektir. Oysa ontolojik ve realist perspektif, bilimin gücünü açıklama gücüne bağlamaktadır. Açıklama da ontolojik temeldeki mekanizmalara, yapılara ve nedensel yasalara ilişkindir. Ancak her şeyi 'açıklamak' ile yanlışlığı konusunda karar 
verilebilir açıklama arasında fark vardır. Epistemolojik sınırlandırma ayracı öngörü önermeleri üzerinden, yanlışlanabilirlikle birlikte doğrudan sınanabilirliğe koyulduğunda, alanındaki her şeyi açıklayabilen teoriler bilim-dışı kalmaktadır. Bunun için Popper'ın epistemolojik kinayesinin hatırlanması yeterlidir: "Bir Marksist eline bir gazete alıp da kendi tarih yorumunu destekleyen tanitlar bulmadan edemezdi; yalnızca haberlerinde değil, gazetenin sınıfsal yanlılığını açığa vuran sunuş biçiminde de ve özellikle yazmadıklarında...” (Popper 2002: 44, 45). Ancak Popper, epistemolojik konumlanması gereği pragmatist olarak değerlendirilebilse de o, aynı zamanda bir realisttir.

$\mathrm{Bu}$ konum benimsendiğinde, bilimi açıklama ve modelleme girişimi için epistemoloji daima odağa daha yakındır ve ontoloji fondaki bir koşuldur. Teoriler arası seçim ya da karşılaştırma yapabilmenin olanağını veren doğruluğa yaklaşma fikri, realist bir dünya görüşü varsayar ve hatta gerektirir. $\mathrm{Bu}$, gerçekliğin herhangi bir teorinin betimlediği gibi olduğunu varsaymaz; bir gerçeklik olduğunu ve fikirler, teoriler, hipotezler olmaksızın da gerçekliğin var olduğunu kabul eder. Böylece, biraz da ironik bir biçimde Wittgenstein'ın Tractatus'unun "dünyanın hiçbir tözü olmasaydı, bir tümcenin anlamlı olup olmadığı, başka bir tümcenin doğru olup olmadığına bağımlı, o zaman da dünyanın (doğru ya da yanlış) bir tasarımını oluşturmak olanaksız olurdu (2006: 19) ifadesindeki 'töz' anlayışına yakın kalınmaktadır. Yine de ironi yüzeyseldir, çünkü bu aşamada bir 'benzetim' ile şu söylenebilir: Neo-pozitivizmin katilinin teorisinde, öldürmüş olduğu teorinin bazı genetik kodları varlığını sürdürmektdir. "Bilim insan fikirlerinin üretim sistemidir: Buraya kadar idealizm haklıdır. Ancak bu fikirler olasılıklar karşısında başarısızlığa uğrayabilir. Bu yüzden sonuç olarak realizm haklidir" (Popper 2015: 37-38). Ancak epistemolojik sürecin problemlerle başlatması ve problemlerle bitirmesi (Popper 2015: 15-19), bu bilgi teorisinin ontolojiyle temasını büyük ölçüde pragmatik kılar. 'Tümcelerin (hatta geniş ölçekte teorilerin ve / veya hipotezlerin) doğruluk / yanlışlı değerlerinin başka tümcelere ya da teorilere bağımlı olmadığını nereden biliyoruz?' sorusunun 'gösterilebilir' tek yanıtı pragmatik yanıttır. $\mathrm{Bu}$ nedenle de Popper kendisini 
metafiziksel realist olarak tanımlar (2015: 77, 78). Çünkü epistemoloji üzerinden (indirgeme hatasına düşmeksizin) ontoloji tesis edilemez. Bu bağlamdaki gerçeklik tanımı (paradigması) fiziksel dünyanın (Popper'ın Dünya 1'i) şeyleridir -taşlar, ağaçlar, hayvanlar. Buna ek olarak, Popper, Dünya 1'deki şeyleri doğrudan veya dolaylı olarak etkileyebilecek şeylere de 'gerçek' demeyi önerir (Popper 2015: 79, 80). Temas, 'bizi etkileyen şeyler ve bu etkileyen şeyleri etkileyen şeyler' üzerinden kurulduğundan tartışma ontolojik değil epistemolojik kalır. Söz konusu olan, bizi etkileyen ve bizim etkileyebileceğimiz şeylerdir ve kimi zaman bu ikisi arasında bir dolayım olarak kimi zaman da bizi etkileyen şeyler olarak temsiller odaktadır. Buna bağlı olarak da gerçeklik ‘temsil problemi' altında tartış̧ıır / tartışılabilir.

Temsil fikri korunarak bu tartı̧̧ma sürdürüldüğünde, yine iki boyut söz konusudur. İlki 'bilimin neyde bu kadar başarılı olduğu' sorusuyla birlikte 'nasıl başarılı olduğu' ve nihayetinde 'neden başarılı olduğu' sorularını kapsayan bilim teorisi (epistemoloji) problemine dairdir. Bu problemi ele alırken, Popper, daha önce de gösterildiği gibi Kant’tan çıkış almaktadır. Fakat Kant'ı geride bırakıp, odağına tümevarımcılığın kökensel zayıflığını koyarken, Kant'ı daha da öteye taşıyacak Kantçı bir hamle yapmaktadır. Kant'1 -odak olarak- geride bırakmış görünmesinin nedeni, tümevarımcıllğın kökensel zayıfllğının doğrudan neo-pozitivist bilim teorisinin hatasını gösterme, diğer bir deyişle de onu çürütme girişiminin en önemli parçası olmasıdır. Oysa bu çürütmeye eklemlediği kendi 'doğruluk iddiasındaki hipotezi' Kant'ın düşüncesini Evrim Teorisi ile birleştirme ya da onu Evrim Teorisi temelinde revize etme önerisini içermektedir.

Popper’a göre, “tümevarımcıllğın nihai zayıflığı, aşırı derecede popüler ve fakat kökensel olarak hatalı bir zihin teorisine, yani tabula rasa teorisine dayanmasinda yatmaktadır" (Popper 2009: XXXVII). Bu teorinin insan zihnini özsel olarak pasif olarak kabul etmesi ve nihayetinde bilginin duyumlarla elde edilen verilerin (diğer deyişle verili olanın) edilgen ifadesinden ibaret kabul edilmesi hatalıdır. Oysa Popper'ın teorisine göre, "hiçbir şey bize verili değildir; duyu organlarımız zaten aktif 
uyarlanmaların, mutasyonların sonucudur ve bunlar hipotezlerin öncülleridir ve tüm hipotezler aktif uyarlanma girişimleridir" (2009: XXXVII). Popper, kendi ifadesiyle teorisinde "uyaran-tepki şeması yerine" "mutasyon-seçilim şeması"nı ikame etmektedir (2009: XXXVII). Mutasyon, özellikle bilinç seviyesinde, aktif ve yeni bir hamledir. Böylece Kant'ın tüm insan varlı̆ı̆nda ortak ve değişmez görü ve kategorileriyle aktif akıl tasarımı, en önemli tespitinde korunarak değişken-aktif bir zihin tasarımına dönüştürülmektedir. O halde, 1978 yılında Popper'ın, Kant'ın teorisinin temelindeki Newton Fiziğinin yerine Darwin'in Evrim Teorisini yerleştirdiği söylenebilir. ${ }^{11}$ Bilim teorisinde böyle bir değişim, bilim teorisini (ya da teorilerini) konu edinen meta-meta konum için de bir değişim anlamına gelecektir. Çünkü bu durumda, bilim teorisini (epistemolojiyi) konu edinen meta-meta teori de mutasyon-seçilim şeması üzerine kurulmak durumundadır ki bu da Popper'ın teorisinin ikinci boyutudur.

\section{Sonuç ve Tartışma: Evrimsel Meta-Teori}

Rorty'nin tezinin aleyhine olacak biçimde, pragmatizm merkezli olarak Rorty ile Popper arasında 'ilginç' bir uyumun açığa çıktığı görülmektedir. Bir tarafta naif realizmle uyumlu kalsa da epistemolojiye 'objektivizm eleştirisi' üzerinden cephe açan ve Kant'ın yarattığı felsefeye dair ben-imajının terk edilmesini 'realizm' - 'pragmatizm' karşıtllğı üzerinden kuran 'pragmatist' Rorty vardır. Epistemolojinin terk edilmesini öneren naif-realist ve pragmatist Rorty, içine düşülebilecek olası bir görelilik girdabından, göreliliği, geleneksel bilgi / kanı ayrımını iptal etmek olarak tanımlayarak çıkmayı hedefler. Böylece bilgi, 'gerekçelendirilmiş iddia edilebilirlik' üzerinden değerlendirilebilir hale dönüştürülür. Diğer tarafta ise rafine hali bilimsel araştırmanın mantığında, yani bilimde olmak üzere başarılı ve hatta tek bir bilgi edinme algoritması olduğunu savunan ve kendisini metafiziksel-realist olarak tanımlayan 'pragmatist' Popper vardir. Metafiziksel-realist ve pragmatist Popper, tam aksine 'inancın yeter nedenlere dayanan şekli' olarak bilgiyi (tam da Rorty'nin kabul edeceği bir bilgi tanımını) bilginin öznel anlamı olarak ve bunun da ötesinde 'eski bilgi teorisini'

\footnotetext{
${ }^{11}$ İlgili metnin yazıldığı tarih 1978'dir.
} 
derinden enfekte etmiş bir tanım olarak bir kenara bırakır. Öznelin karşısına nesneli çıkartarak "dil aracılığıyla formüle edilmiş önermelerden, hipotezlerden ve problemlerden" oluşan ve gerçeklik üzerinden hiçbir zaman doğrulanamasalar bile, yanlış olan hipotezlerin elenebildiği bir bilimi öne sürer. Hem de bilginin daima hipotetik kalacağını rahatlıkla kabul ederek (klasik bilgi / kanı ayrımına başvurmayı gereksiz kılarak) bu nesnelliği kurabilmektedir.

İlginçlik buradadır; Popper 'temsil problemi'ni bir sözde-probleme dönüştürmeden ve ulaşılabilir nesnel gerçekliği terk etmeksizin bir pragmatisttir. Yani, Kant'tan (geniş anlamıyla ve sadece bu çalışmanın çerçevesi bağlamında) bir pragmatizm türetilmektedir. Oysa Rorty, tam da bunların terkedilmesine paragmatizm demektedir. Popper'ın realizmi metafizik realizmdir ve bilimin gerçeklikle temasının güvencesi empirik yüzey üzerinden pragmatik bir temastır. $\mathrm{Bu}$ pragmatik temas, gerçeklik betimi (temsili) olarak teoriyi yanlışlamadığı sürece teorinin gerçekliği ya da onun bir kısmını ifade ettiği varsayımı da yanlışlanmamış olur. Bu nedenle Popper'ın yaklaşımı araçsalcı olmayan bir pragmatizm içermektedir. Bu da kaba anlamıyla da olsa, Kant'ın fenomenal dünyasını koşullayan arkitektoniğin a priori evrenselliğinin iptal edilip, yerine en geniş anlamıyla teorik düzeyde açığa çıkan, çeşitlenen ve numenal alanla pragmatik temasında elenen (elenebilen) hipotetik çerçeveleri yerleştirmektir. Numenal alan, artık kategorik olarak bilinemez kalmaya yazgılı ontolojik bir sınırsızlık değildir. Henüz elenmemiş ve elenenlerin yerini alan yeni hipotetik çerçevelere göreli olarak değişken sınırları git gide daralan bir gerçeklik alanıdır.

Doğruluğun evrensel bir ölçütünün olmamasından (kuşkuculuğun klasik formülasyonundan) bilimlerde hiçbir ilerleme olmadığı sonucu çıkmaz. İnsanın 'gerçek anlamılla' (buradaki 'gerçek anlam' doğruluk ile yakından ilişkilidir) gerçekliği bilemeyeceği fikri ile bir doğruluk ölçütü ve / veya kesin-doğru bilgi olmaksızın da bilgimizi arttırabileceğimiz fikri açıkça birbirinden farklıdır. Bu farklılaşmayı açık olarak görebilmek için epistemoloji tarihinin evrimsel olduğu yönlü meta-teoriyle bakmak gerekmektedir. Epistemoloji, artık işlevini kaybetmiş eski bir 'araç' ya da 
'temellendirici felsefe' anlayışının kronik hastalığından mustarip akademik felsefenin 'temelsiz temeli' değildir. Epistemoloji, Poppercı çerçevesinde nesnesiyle ilişkisinde evrimsel olarak dönüşen ve mevcut hali Einstein Devrimine verdiği tepki üzerinden biçimlenmiş bir meta-teoridir.

Ulaşılan bu 'sonuç', epistemoloji üzerine geliştirilebilecek bir meta-hipotezdir (en azından bu çalışma sınırlarında) ve "epistemolojinin ölümü” problemiyle ilişkili bütün bir problem ağını aydınlatma ve bu ağın büyük bir bölümüne çözüm getirme potansiyelini barındırmaktadır. Kant, bu hipotezin kaynağında yer alan Popper Teorisinin -bir benzetimle- genetik atasıdır. Diğer yandan, bir meta-teori olarak 'Rorty 'Teorisi'nin çerçevelediği epistemolojinin ölümü tezinde Kant, epistemolojinin ölümünün tarihsel kırılma anı ve hatta kanıtıdır. Ancak Popper Teorisi, epistemoloji üzerine bir meta-teori olarak kullanıldığında, iki meta-teori Kant’ta kesişmekte ve yine bir benzetimle Kant üzerinden çeşitlenen kuzen-teoriler olarak konumlanabilmektedirler. Görünen odur ki, Popperyen hat hayattadır ve hayatta kalacaktır. 


\section{KAYNAKÇA}

AYER, A. Jules (1998). Dil, Doğruluk ve Mantık, çev. Vehbi Hacıkadiroğlu, 2. Basım, İstanbul: Metis Yayınları.

BAUM, Manfred (1979). "Transcendental Proofs In Critique of Pure Reason," Transcendental Arguments and Science -Essays in Epistemology-, ed. Peter Bieri, RolfP. Horstmann, Lorenz Krüger, pp. 3-26. London: D. Reidel Publishing Company.

BHASKAR, Roy (2017). Insan Bilimlerinin Felsefi Eleştirisi -Natüralizmin Olanaklılı̆̆l-. çev. Vefa Saygın Ögü̈le, Ankara: Nika Yayınevi.

CARNAP, Rudolf (1966). "The Elimination of Metaphysics Through Logical Analysis of Language," trans. by Arthur Pap, Logical Positivism, ed. A. J. Ayer, pp. 6081, New York: The Free Press.

COMTE, Auguste (2015). Pozitif Felsefe Dersleri ve Pozitif Anlayış Üzerine Konuşma, çev. Erkan Ataçay, Ankara: BilgeSu Yayıncılık.

FRIEDMAN, Michael (2015). Kant ve Kesin Bilimler, çev. Sibel Şan Öğet, İstanbul: Alfa Basım Yayım.

HAACK, Susan (2017). "Fight For Our Philosophy, The Real Question: Can Philosophy Be Saved?", Free Inquiry, 37 (6): 40-43.

HACKING, Ian (2016). Temsil ve Müdahale -Doğa Bilimleri Felsefesine Girişte Temel Konular-, çev. Ozan Altan Altınok, İstanbul: Alfa Basım Yayım.

KANT, Immanuel (2000). Gelecekte Bilim Olarak Ortaya Çıkabilecek Her Metafiziğe Prolegomena, çev. İonna Kuçuradi-Yusuf Örnek. 4. Baskı [4. Baskıyı yayına hazırlayan: Harun Tepe], Ankara: Türkiye Felsefe Kurumu.

KANT, Immanuel (2015). Arı Usun Eleştirisi, çev. Aziz Yardımlı, 4. Baskı. İstanbul: İdea Yayınları.

MASTERMAN, Margaret (2017). "Paradigmanın Doğası", çev. Nur Küçük, Eleştiri ve Bilginin Gelişmesi, ed. Imre Lakatos, Alan Musgrave, ss.80-122, İstanbul: İthaki Yayınları.

MIELANTS, Eric (2007). "Tepki ve Direniş: Doğa Bilimleri ve Beşerî Bilimler, 1789-1945”, çev. Aysun Babacan, İki Kültürü Aşmak, ed. R. E. Lee, I. Wallerstein, ss. 50-76, İstanbul: Metis Yayinlar1.

POPPER, Karl R. (2002). Conjectures and Refutations, London: Routledge.

POPPER, Karl R. (2005). Unended Quest - An Intellectuel Autobiography, London: Routlegde. 
POPPER, Karl R. (2009). Two Fundamental Problems of the Theory of Knowledge. trans. by Andreas Pickel, ed. Troels Eggers Hansen, London and New York: Routledge

POPPER, Karl R. (2010). Daha İyi Bir Dünya Arayışı -Son Otuz Yılın Makaleleri ve Bildirileri-, çev. İlknur Aka, 3. Baskı, İstanbul: Yapı Kredi Yayınları.

POPPER, Karl R. (2010b). Açık Toplum ve Düşmanları-Cilt 1-, çev. Mete Tunçay, 4. Baskı, İstanbul: Liberte Yayınları.

POPPER, Karl R. (2012). Bilimsel Araştırmanın Mantı̆̆ İbrahim Turan, 5. Baskı, İstanbul: Yapı Kredi Yayınları.

POPPER, Karl R. (2015). Hayat Problem Çözmektir -Bilgi, Tarih ve Politika Üzerine-, çev. Ali Nalbant, 5. Baskı, İstanbul: Yapı Kredi Yayınları.

REICHENBACH, Hans (1936). "Logistic Empiricism in Germany and the Present State of its Problems", The Journal of Philosophy, 33(6): 141-160.

REICHENBACH, Hans (1938). Experience and Prediction, USA, Chicago: The University Of Chicago Press.

REICHENBACH, Hans (1968). The Rise of Scientific Philosophy, Berkeley and Los Angeles: University of California Press.

REISCH, George A. (2016). Soğuk Savaş Bilim Felsefesini Nasıl Dönüştürdü Mantığın Buzlu Yokuşlarında-, çev. Meriç Mete, İstanbul: İdea Yayınları.

RORTY, Richard (1995). Olumsallık Ironi ve Dayanışma, çev. Mehmet Küçük, Alev Türker, İstanbul: Ayrıntı Yayınları.

RORTY, Richard (1997). "Introduction", Objectivity, Relativism and Truth Philosophical Papers Volume 1-, pp. 1-20, Cambridge: Cambridge University Press.

RORTY, Richard (1997b). "Solidarity or Objectivity", Objectivity, Relativism and Truth -Philosophical Papers Volume 1-, pp. 21-34, Cambridge: Cambridge University Press.

RORTY, Richard (1997c). "Science as Solidarity", Objectivity, Relativism and Truth -Philosophical Papers Volume 1-, pp. 35-45, Cambridge: Cambridge University Press.

RORTY, Richard (1997d). "Pragmatism without Method", Objectivity, Relativism and Truth -Philosophical Papers Volume 1-, pp. 46-77, Cambridge: Cambridge University Press.

RORTY, Richard (1997e). "Texts and Lumps", Objectivity, Relativism and Truth -Philosophical Papers Volume 1-, pp. 78-92, Cambridge: Cambridge University Press. 
RORTY, Richard (1997f). "Inquiry as Recontextualization", Objectivity, Relativism and Truth -Philosophical Papers Volume 1-, pp. 93-110, Cambridge: Cambridge University Press.

RORTY, Richard (1997g). "Non-Reductive Physicalism”, Objectivity, Relativism and Truth -Philosophical Papers Volume 1-, pp. 113-125, Cambridge: Cambridge University Press.

RORTY, Richard (1997h). "Pragmatism, Davidson and Truth", Objectivity, Relativism and Truth -Philosophical Papers Volume 1-, pp. 126-150, Cambridge: Cambridge University Press.

RORTY, Richard (1999a). "Philosophy as Science, as Metaphor, and as Politics”, Essays on Heidegger and Others -Philosophical Papers Volume 2-, pp. 9-26, Cambridge: Cambridge University Press.

RORTY, Richard (1999b). "Heidegger, Contingency, and Pragmatism", Essays on Heidegger and Others -Philosophical Papers Volume 2-, pp. 27-49, Cambridge: Cambridge University Press.

RORTY, Richard (1999c). "Two Meanings of 'Logocentrism"”, Essays on Heidegger and Others -Philosophical Papers Volume 2-, pp. 107-118, Cambridge: Cambridge University Press.

RORTY, Richard (2006). Felsefe ve Doğanın Aynası, çev. Funda Günsoy Kaya, İstanbul: Paradigma Yayınları.

RUSSELL, Bertrand (1996). Dış Dünya Üzerine Bilgimiz, çev. Vehbi Hacıkadiroğlu, İstanbul: Kabalcı Yayınevi.

SCHLICK, Moritz (1966). "The Turning Point in Philosophy", trans. by David Rynin, Logical Positivism, ed. A. J. Ayer, pp. 53-59. 2nd Printing, New York: The Free Press.

SNOW, Charles P. (2010). İki Kültür, çev. Tuncay Birkan, Ankara: Tübitak Popüler Bilim Kitapları.

WITTGENSTEIN, Ludwig (2006). Tractatus Logico-Philosophicus, çev. Oruç Aruoba, İstanbul: Metis Yayınları. 